\title{
The drivers of prejudice with a special focus on religion-insights into anti-Muslim sentiment in Austrian society
}

\author{
Wolfgang Aschauer
}

(C) The Author(s) 2020

\begin{abstract}
Terrorist attacks, refugee movements from crisis regions as well as barriers to integration among immigrants have also been increasing fears of Islam in Austria, whereby Muslims are often regarded all too generally as outsiders to Austrian society. In this article the results of a representative study (Social Survey Austria 2018) are presented, which includes the first time a sophisticated scale on attitudes towards Muslims. In addition, a sequential multiple regression analysis will be used for a more detailed analysis of classical factors influencing critical attitudes towards Islam, whereby a new research gap will be addressed focusing on religious attitudes and practices of Austrians. The analysis of the extent of antiMuslim sentiment in Austria reveals a dominant critical view. However, the influences of religious orientations are manifold: While conventional religious practice (such as church attendance and praying) as well as superstition reinforces animosities, inclusive religious attitudes and individual practices of spirituality lead to more tolerant attitudes. The results, which indicate a tendency towards greater tolerance among religious people, show that we are in Austria mainly confronted with cultural rather than interreligious conflicts, which are primarily centered around identity and recognition.
\end{abstract}

Keywords Anti-Muslim sentiment $\cdot$ Ethnic prejudice $\cdot$ Austria $\cdot$ Religious attitudes $\cdot$ Multiple regression analysis 


\section{Religiöse Einstellungen als Einflussfaktor für Vorurteile oder Toleranz? Eine Analyse islamkritischer Haltungen in Österreich}

Zusammenfassung Terroristische Anschläge, Fluchtbewegungen aus Krisenregionen sowie Integrationshürden für muslimische Zugewanderte nähren auch in Österreich seit vielen Jahren Ängste vor dem Islam, wobei MuslimInnen oft allzu verallgemeinernd als Außenstehende der österreichischen Gesellschaft betrachtet werden. Im vorliegenden Beitrag sollen auf Basis einer umfassenden Skala antimuslimischer Ressentiments, die Bestandteil des Sozialen Surveys Österreich 2018 war, erstmals differenzierte Aussagen zum Ausmaß islamkritischer Haltungen getroffen werden. Zusätzlich erfolgt mit einer sequentiellen multiplen Regressionsanalyse eine nähere Analyse klassischer Einflussfaktoren auf islamkritische Haltungen, wobei mit der besonderen Berücksichtigung religiöser Einstellungen und Praktiken der ÖsterreicherInnen neues Forschungsterrain beschritten wird. Analysiert man das Ausmaß antimuslimischer Ressentiments in Österreich, so wird eine dominant kritische Sichtweise deutlich. Vielschichtig sind jedoch die Einflüsse religiöser Orientierungen: Während konventionelle religiöse Praktiken (wie kirchliche Aktivitäten oder Beten) und auch abergläubische Haltungen Animositäten verstärken, bewirken inklusive religiöse Haltungen und individuelle Praktiken der Spiritualität tolerantere Haltungen. Die Ergebnisse, die auf eine tendenziell größere Toleranz bei religiösen Menschen hindeuten, zeigen also, dass wir aktuell in Österreich eher mit kulturellen Konflikten um Anerkennung, Identität und Zugehörigkeit als mit interreligiösen Konflikten konfrontiert sind.

Schlüsselwörter Antimuslimische Ressentiments · Vorurteilsforschung · Österreich · Religiöse Einstellungen · Multiple Regressionsanalyse

\section{Introduction: the necessity to study Anti-Muslim sentiment in Austria}

Theoretical and empirical research on attitudes towards immigrants has already been conducted over several decades and there is plenty of evidence about the dynamics of prejudice (e.g. for a recent review Ceobanu and Escandell 2010). There are also elaborate findings on the links between religious attitudes and ethnic prejudice, which date back to the beginnings of prejudice research (e.g. Allport 1954). A contrasting picture emerges, however, when we look at the attitudes of the majority population towards Muslims. Cross-national studies looking at attitudes are limited to the collection of single indicators (e.g. Strabac and Listhaug 2008; Storm 2012; Yendell and Friedrich 2012; Pollack et al. 2014; Pickel and Yendell 2016), and even in European countries there are hardly any surveys that enable a differentiated measurement of anti-Muslim sentiment (e.g. Pollack et al. 2014 for an exception). However, at least in the German-speaking world, research has been carried out in recent years that increasingly refers to intercultural tensions between the majority society and Muslims, and addresses the role of potential interreligious conflicts (e.g. Küpper and Zick 2014; Rebenstorf 2018; Pickel and Pickel 2019). 
So we can say that Islamophobia is an emerging concept in the research on ethnic prejudice (e.g. Stolz 2005; Kühnel and Leibold 2007; Helbling 2012; Aschauer 2017) but an empirically sound elaboration is still in its infancy (already Fetzer and Soper 2003, p. 248). This is also due to the fact that up to now critical attitudes towards Muslims in particular can hardly be distinguished from critical attitudes towards immigrants in general (see for instance Helbling 2012, pp. 10f.). Although some enduring antecedents of Islamophobia may be generally subsumed under xenophobia (e.g. Helbling 2010), there might be emerging drivers of prejudice which may contribute specifically to explaining anti-Muslim sentiment. This article tries to address this research gap by focusing on religious beliefs, attitudes and practices which may have a specific impact on attitudes towards Muslims. The relationship between religiosity, xenophobia in general and Islamophobia in particular is still unclear and it is an open question in research whether different aspects of religiousness increase or reduce prejudice (e.g. Burch-Brown and Baker 2016). The database of the Austrian Social Survey 2018 (Sozialer Survey Österreich, SSÖ) enables on the one hand a differentiated measurement of anti-Muslim sentiment based on a sophisticated scale, and on the other hand a multifaceted measurement of religiosity. This is the case, because the Austrian Social Survey (SSÖ) is part of the ISSP program, where the 2018 wave included a special module on religion. This specific constellation of the survey allows the analysis of the extent of anti-Muslim sentiment in Austria and enables a comprehensive analysis of the main antecedents of Islamophobia for the first time. The analysis combines classical background variables, cultural and economic impact factors and religious beliefs, practices and attitudes in a multiple regression design.

Apart from these empirical advantages, a case study of Austria is of particular interest. Various developments in Western society (e.g. the rise of right-wing populism and ongoing challenges of migrant integration and social cohesion) are somewhat more pronounced in Austria compared to other European countries. In this country, right-wing populism has a long tradition because the Freedom Party (FPÖ) has long been present in the political landscape and has gained popularity among a broad spectrum of voters over the past two decades. ${ }^{1}$ In addition, the People's Party with its current prime minister Sebastian Kurz, has propagated an anti-Muslim agenda over the years. ${ }^{2}$ Both parties claim to speak for the majority of the native population and tend to view parts of the Muslim population as "significant others" (Triandafyllidou 1998, p. 593) who are perceived as a threat to Austrian culture.

The objective of this study is to investigate the cognitive reasoning and the emotional reactions of the Austrian population towards Muslims and to shed light on the main antecedents of anti-Muslim sentiment with a special focus on religion. Sect. 2 focuses on the dependent variable and presents fruitful ways to capture the

\footnotetext{
1 As a result of the 2017 elections, the Freedom Party took on government responsibilities and formed a coalition with the Austrian People's Party (ÖVP) until the so-called Ibiza-scandal led to an abrupt end of this coalition.

2 The former and new federal chancellor, Sebastian Kurz, clearly won both elections because he was able to precisely capture the diffuse fears of the Austrian population and the spirit of political change in the country.
} 
multifaceted and challenged concept of Islamophobia with a sophisticated scale. Subsequently, the main theoretical approaches on enduring and emerging explanatory factors with a special focus on religion are highlighted which represent the core research agenda of the article. The bridge to the empirical part (Sect. 4) is built by describing the operationalization of indicators and concepts which were used in the study and by deriving various assumptions which finally guide the empirical analysis (Sect. 5). In the conclusion of the article the main results are discussed and embedded in current literature (Sect. 6).

\section{Analyzing attitudes towards Islam-a challenging endeavor}

The emergence of anti-Muslim prejudice in the West is usually traced back to the time of the collapse of the Soviet empire, although some authors attribute the origins of anti-Muslim sentiment to former times (e.g. Commission of British Muslims and Islamophobia 2004; Poynting and Mason 2007). In Austria, the roots of critical attitudes towards Islam can be traced back to notable signal events in history. The siege of Vienna by the Turks is often used as a metaphor to warn of Muslims undermining the culture of Austria (for a sophisticated historical analysis of prejudice in Austria see Hämmerle 2018). Catholicism is also often depicted as a boundary against Islam, especially by authors who are active in spreading neoconservative ideologies (e.g. Kurth 2006 as an example). The Commission of British Muslims and Islamophobia (1997) were the first introducing the term Islamophobia to a wider public and trying to recognize the multidimensionality of the construct. They considered views of Muslims either as open or as closed. An Islamophobic attitude represents a view of Muslims as a static community, it perceives them as different and separated, interprets them as inferior, barbaric and primitive, and construes them as hostile and therefore potentially violent and susceptible to terrorism. Finally, Islam is seen in a pejorative attitude as a manipulative political ideology immune to Western criticism (see Commission on British Muslims and Islamophobia 1997, p. 5).

Due to the verbal expression of phobia, which refers to a pathological fear, it seems fruitful to take perceptions of threats into account when constructing a scale. This is the primary research aim of Lee et al. (2009), who established a scale to measure negative feelings towards Muslims and their religion (see Lee et al. 2009, p. 93). In the psychometrically tested scale of 16 items, two independent dimensions could be distinguished, an affective-behavioral subscale, which is directed to negative emotions and behaviors towards Muslims, and a cognitive subscale, which results in an interpretation of Islam as dangerous religion. ${ }^{3}$

It is noteworthy however, that even within the liberal spectrum of society, criticism of Islam is often expressed, especially concerning the role of religion. Left-

\footnotetext{
3 However, the authors measure more or less the same aspects ("Islam is a dangerous religion", "Islam is an evil religion", "Islam is a religion of hate") with several items. With this strategy it is easy to achieve a high internal consistency of the scale (see Lee et al. 2009, p. 98) but the content validity of the scale is limited due to the narrow focus.
} 
wing politicians fear a rejection of Western emancipatory achievements and often implicitly see Muslims as backward, unwilling to follow a secular lifestyle and to adapt to Western gender roles. Soon after the establishment of the term Islamophobia (e.g. Allen 2007) the debate surrounding the phenomenon became highly polarized and supporters and opponents of Muslim immigration started to use the term also in a strategical sense. The main proponents of critique on Islam see Islamophobia as a discursive weapon to suppress the legitimate criticism of religious practices and fundamentalist tendencies. In their view, freedom of expression is restricted and misinterpreted as a prejudiced opinion. That is the reason why I refrain from the term Islamophobia in this study because we generally find a highly pluralistic spectrum of attitudes among the population. It is impossible to decide from single statements and item distributions about the extent of "Islamophobia" because we are always confronted with a continuum from tolerant worldviews to critical statements, prejudiced views or even discriminatory attitudes. It is much more interesting to examine the different dynamics leading to anti-Muslim sentiment in order to be able to distinguish between a liberal-secular critique and open anti-Muslim racism. This was also the main objective of the scale of Imhoff and Recker (2012), to isolate a secular-rational motivated form of criticism of Islam which is independent from Islamophobic tendencies. ${ }^{4}$

Helbling (2010) raises the question of whether critical attitudes towards Muslims illustrate a specific form of prejudice or may be generally subsumed under xenophobia. In Germany at least, there are some efforts to analyze the interrelations of various forms of prejudice in research. The most notable example is the concept of "group-focused enmity" by the Bielefeld-research group (e.g. Heitmeyer 2002-2012; Zick et al. 2011). Here Islamophobia is treated as one facet of this general syndrome of hostile attitudes which can all be traced back to an ideology of inequality (Heitmeyer 2007). Due to the complexity of the concept, all facets of group-focused enmity are measured with just a few items, which were also subject to criticism. ${ }^{5}$ But the empirical results of the group-focused enmity studies clearly indicate high correlations between ethnic prejudice and Islamophobia (see Zick et al. 2008), which strengthens the position that Islamophobia cannot be distinguished from other forms of racism. In this study it is not possible to test for similarities between ethnocentrism and anti-Muslim sentiment because the SSÖ 2018 exclusively measures critical attitudes towards Muslims. But it is possible to explore potentially different dimensions of anti-Muslim sentiment and to estimate the extent of po-

\footnotetext{
4 Nevertheless, the final version of the scale is based on student samples and the scale is not suitable for representative population surveys. The items require a high level of education for an adequate understanding. The authors propose for instance, the following item to measure prejudice: "Muslim cultures have such fundamentally different values, that it is difficult to identify common aims or ideals." The secularrational critique is measured by the following statement: "The rigid Islamic gender division should not be conceded to-neither in the public health sector nor in physical education." (vgl. Imhoff and Recker 2012, p. 815).

5 From year to year only a few indicators on Muslims were kept constant (e.g. "Due to Muslims I feel like a stranger in my own country") while other items were often modified due to criticism or poor item quality (e.g. "Islam has developed an admirable culture", "Islam belongs in Germany") (see GESIS variable reports, Group Focused Enmity Studies 2013).
} 
tential prejudice among the population. Additionally, the sophisticated scale, which is implemented in the survey, allows some comparisons of the Austrian situation with other European countries. Concerning the indicators measuring attitudes towards Muslims, I propose that all items are clearly interrelated and thus lead to one superordinate factor of anti-Muslim sentiment (hypothesis 1). On the other hand, I assume that there are at least gradual differences in the extent of critical attitudes towards Muslims when it comes to certain dimensions of threat which are depicted in the scale (hypothesis 2). The third part of this descriptive analysis of the extent of anti-Muslim sentiment in Austria includes a cross-country comparison. Due to the ongoing negative discourse on anti-Muslim sentiment, I assume that critical attitudes towards Muslims are higher in Austria compared to other European states (hypothesis 3$)^{6}$

The second main research aim of the study is to shed light on the antecedents of anti-Muslim sentiment in Austrian society. The next section summarizes the current literature and sets out further assumptions. These are subsequently tested with a comprehensive multiple regression analysis using explanatory variables on three explanation levels, and an index on anti-Muslim sentiment as the outcome variable (see Sect. 4 for operationalization).

\section{The drivers of anti-Muslim sentiment with a special focus on religion}

When it comes to the main drivers of anti-Muslim sentiment, several empirical studies (e.g. Stolz 2005; Kühnel and Leibold 2007; Strabac and Listhaug 2008) conclude that roughly the same explanatory factors are responsible for ethnic prejudice and anti-Muslim sentiment. Therefore, it is assumed that classical antecedents of ethnic prejudice (the first level of sociodemographic and socio-structural factors) are equally valid for anti-Muslim sentiment. It is often found in literature that older people are less prejudiced towards immigrants while either no clear or mixed results are found regarding gender (e.g. Chandler and Tsai 2001). ${ }^{7}$ Educational level is generally identified as one key determinant of ethnic prejudice (Hello et al. 2002; Coenders and Scheepers 2003). Meeusen, de Vroome, and Hooghe (2013) found that cognitive skills seem to be relevant for coping with social complexity and for feeling more secure in different interaction settings. Thus, apart from education, a higher socioeconomic status tends to be negatively correlated with prejudice (Semyonov et al. 2004). Another consistent result is that people living in urban areas exhibit lower levels of prejudice (e.g. Coenders and Scheepers 2008).

With regard to those studies, I expect that sociodemographic and socio-structural indicators exert notable influences on anti-Muslim prejudice in Austria which are fully consistent with international research. It is assumed that older participants demonstrate higher prejudice towards Islam (hypothesis 4). I also expect a clear

\footnotetext{
${ }^{6}$ Due to the lack of comparable indicators across Europe, this comparison has to be treated with caution. The study by Pollack et al. (2014), however, makes it possible to relate Austrian judgements to attitudes in other countries, because at least seven out of eleven indicators were used in both studies.

7 This is the reason why gender is not integrated in the multiple regression model (see Sect. 5).
} 
effect regarding education, with people with higher education exhibiting lower prejudice towards Muslims (hypothesis 5). With regard to higher status (measured by household income), I hypothesize that people with a higher income may be more tolerant towards Muslim (hypothesis 6). The same should be true for domicile, with people in urban areas seeing Muslims pore positively (hypothesis 7). I additionally controlled for migration background and religious denomination assuming no impact on anti-Muslim sentiment when people with Islamic religious denomination are not further considered in the sample (hypothesis 8 ). ${ }^{8}$

Besides those classical predictors of ethnic prejudice, it is necessary to go deeper into theory and to introduce crucial attitudinal characteristics which may have an impact on anti-Muslim prejudice as well. Western European countries often struggle with how to promote the integration of Muslim immigrants because of their educational underachievement, underprivileged positions in the labor market, and unemployment rates which often remain higher compared to other groups (see recent results for Austria in Aschauer et al. 2019). This leads to exclusionary attitudes among natives in low-skilled occupations, because immigrants in general are perceived as competitors on the labor market.

Social identity theory might also come into play here because people at the lower end of society tend to stabilize their identity by devaluing out-groups which they perceive as a threat to their identity (see prominently Tajfel and Turner 1979). This threat-according to Steele et al. (2002) — can be nurtured by various aspects that increase animosity and ethnic rivalry based on low group status on both sides. Quillian (1995) has put those dynamics in two simple theses. The larger the proportion of immigrants and the more difficult the economic conditions in a country are, the more prejudice arises among the citizens. This thesis of the ethnic group threat has been confirmed several times in the United States (e.g. Taylor 1998) and has led to broad research activities in recent years but the results for Europe are more mixed (e.g. Kunovich 2004; Semyonov et al. 2006). This may be a first hint to extend classical research on social structure and ethnic prejudice to anti-Muslim sentiment, because here underprivileged positions in the labor market are often interpreted through a cultural lens (e.g. Hall 1989). It is necessary to consider relative deprivation theory (firstly developed by Stouffer 1949), which focuses on perceptions of potential disadvantages in comparison to other persons and on negative future prospects. The frustration of being underprivileged may be transferred to scapegoating with respect to other weak groups in society (see the frustration-aggression thesis, originally from Dollard et al. 1971).

The measurement of subjective perceptions is done with two status indicators, the subjective position in society, and their ability to manage household income (see Sect. 4.3). When people rank themselves at a lower societal level and have difficulties in managing their income, they may feel economically threatened by immigrants which would increase anti-Muslim sentiment (hypothesis 9). Feelings of being underprivileged together with fears of social decline more precisely measure

\footnotetext{
8 It is obvious that Muslims react with more tolerance regarding their in-group and their own (religious) community. Thus it was decided to delete participants with an Islamic denomination from the sample. This leads to a final sample of $n=1147$ for the regression analysis.
} 
perceptions of being disadvantaged compared to others. If people perceive their lives as getting worse and if they express a high level of future pessimism with regard to Austria, then Muslims may serve as scapegoats for societal transformation. Thus it is assumed that both factors exert an influence on the outcome variable (hypothesis 10).

Additionally, it seems worthy to take perceptions of cultural threat and certain aspects of societal discontent more adequately into account. This strategy of emphasizing certain cultural characteristics in order to gain political profit has become particularly relevant in the wake of the ongoing terrorist threat and the refugee crisis. If the people have the feeling that they are uninvolved bystanders witnessing rapid processes of social change, feelings of political alienation will grow. Then the elites are blamed for the influx of Muslims, which may go hand in hand with a rise in institutional and social distrust and negative prospects for the future. These impressions may lead to critical assessments of cultural diversity (e.g. Schneider 2008) and may increase feelings of superiority compared to Muslims. In general, Muslims are subsequently classified as different, not fitting into Western culture and only slightly willing to integrate (e.g. Pickel and Pickel 2019, p. 306). This idea, which is clearly promoted by the radical right all over Europe, associates a whole religious group with negative stereotypes and ascribes a lower status to them. This means that Muslims in general are confronted with the threat of being stereotyped, which may affect their performance in the West as well as a lack of recognition (e.g. Appel 2012, p. 485). In a kind of vicious circle people tend to generalize and devalue cultural habits and various modes of living while at the same time Muslims have the feeling that their efforts to integrate do not fit into the Western ideology of achievement. Here, social distrust can be a powerful concept, clearly indicating potential hostility towards out-groups (hypothesis 11). In general, it is thus assumed that indicators of political dissatisfaction (e.g. lack of political efficacy and institutional distrust) exert a higher impact on anti-Muslim sentiment than aspects of economic deprivation (hypothesis 12).

When groups with a certain religious denomination are blamed for their lack of integration, the different varieties of religiosity within the majority populations might play a significant role in intercultural encounters. A first essential distinction of the influence of religion on attitudes towards immigrants has already been made by Gordon W. Allport (1954), one of the pioneers of ethnic prejudice research. As early as the 1960s, he found that a higher frequency of churchgoing was associated with higher levels of prejudice. Moreover, those who have an exclusive understanding of religion (and thus place their own religion above others) are more susceptible to ethnic prejudice, while those with an inclusive understanding of religion show more tolerance (e.g. in particular Allport and Ross 1967). These theses have been confirmed in many cases in the US (also on the basis of meta-analyses; see Hall et al. 2010) and may be particularly relevant for enhancing an interreligious dialogue with Muslims. For example, Rebenstorf (2018) found in a study based on the 2008 European Values Study data that an exclusive understanding of religion ("There is only one true religion") is accompanied by a stronger rejection of Muslims as neighbors, while an inclusive approach ("Every religion contains truths") leads to greater acceptance (see Rebenstorf 2018, p. 327). 
In line with the research literature, it is assumed that conventional religious beliefs and practices are associated with a traditional (more exclusive) understanding of religion and therefore encourage anti-Muslim sentiment (hypothesis 13). But this one-sided interpretation of religiosity is not suitable anymore because the field of religious attitudes is becoming more and more diversified and is characterized by processes of individualization, privatization and subjectivity (e.g Knoblauch 2018). Interestingly, when people view religiosity as a central personal value to search for meaning in life, often lower prejudice has been reported (e.g. Batson et al. 1993). In a Belgian study, for example, Saroglou et al. (2009) found that secularly oriented persons are more strongly opposed to the headscarf, while spiritually oriented persons show more tolerance. The authors attribute this to the fact that a spiritually oriented lifestyle crosses boundaries between ingroups and outgroups and could promote values such as universalism and interreligious sensitivity (Saroglou et al. 2009, p. 421). An interesting theory in this regard is the religious coping theory, which suggests that people maintain a constructive relationship with issues they consider as sacred (for an early example see Pargament 1997). When people perceive that the sacred is violated, they may react with more tolerance towards other religions, because they want to protect their cherished values. When people are in favor of religion having a more prominent place in society and see a deeper meaning in a religious life, they may react with more tolerance towards Muslims because they appreciate the value they place on religion especially compared to those who favor a strict secular orientation. It is hypothesized that various religious attitudes and practices indicating an inclusive understanding of religion (e.g. Allport and Ross 1967), for example believing that religion should have a prominent place in society, searching for a deeper meaning through religion, and striving for a spiritual life, might increase tolerant attitudes towards Muslims (hypothesis 14).

In addition to religious practices and attitudes, the so-called "para-beliefs" could also have an impact on anti-Muslim attitudes. Superstitious phenomena are also quite common in society and represent forms of a non church-based faith (e.g. Terwey 2012, pp. $109 \mathrm{ff}$.). Here a certain proximity to conspiracy thinking could become apparent, because Adorno et al. (1950) already described superstition and rigid beliefs as potential facets of authoritarianism which may increase hostility towards outgroups. Thus, superstition may be connected with a higher susceptibility to stereotypes and with higher anti-Muslim sentiment (hypothesis 15).

\section{Methodological procedures of the study}

The following results and the operationalization of the key variables of this study are based on the Social Survey Austria 2018. The sample consists of 1200 respondents (aged over 18 years), who were randomly selected from households and interviewed in the CAPI-Mode (Computer-Assisted Personal Interviewing). ${ }^{9}$ The SSÖ data usually show only minor deviations from the distribution of the Austrian population.

\footnotetext{
9 The dataset as well as the method report with an elaborate description of the sample can be found in the Austrian Social Survey (Sozialer Survey Österreich, SSÖ) Data Archive (Hadler et al. 2019).
} 
In order to compensate for different selection probabilities at the household level, and to adjust the data to the overall Austrian distribution, a design weighting and an adjustment weighting were used (see in detail Prandner 2019, pp. 220-224). In the following tables, the distributions are reported based on raw samples. However, mean values, standard deviations, and frequencies are always reported in weighted form in order to be able to draw conclusions about the Austrian population. In this section all variables of the study are further described, and descriptive results and reliability statistics are reported. First I highlight the operationalization of the main outcome variable of the study (anti-Muslim sentiment), and then I refer in detail to all selected independent variables which were used to explain that sentiment.

\subsection{The operationalization of anti-Muslim sentiment}

The items for measuring critical attitudes towards Muslims, which make up the scale, are based on preliminary studies and pretests. I follow a broad understanding of anti-Muslim sentiment — in line with Bleich (2011) ${ }^{10}$ — to shed light on potential underlying dimensions which represent negative stereotypes and critical feelings. These dimensions were refined in qualitative interviews to explore the underlying arguments of Austrian citizens and have already been integrated in the AttitudesTowards-Muslims-Scale (Aschauer 2017). Due to constraints regarding the length of the SSÖ-Survey, it was not possible to integrate all underlying dimensions of the original ATMS-scale but at least 11 items were used to measure anti-Muslim sentiment. The items were further modified to enable comparisons with a recent

Table 1 Underlying dimensions and indicators to measure anti-Muslim sentiment in Austria (SSÖ, 2018)

\begin{tabular}{|c|c|}
\hline $\begin{array}{l}\text { Dimensions of } \\
\text { critical attitudes }\end{array}$ & Item selection \\
\hline \multirow[t]{2}{*}{ Muslims as cultural threat } & $\begin{array}{l}\text { The growing number of Muslims can be seen as a cultural enrich- } \\
\text { ment for Austria. }{ }^{\text {a }}\end{array}$ \\
\hline & $\begin{array}{l}\text { Due to the presence of Muslims, I sometimes feel like a stranger in Aus- } \\
\text { tria }\end{array}$ \\
\hline \multirow[t]{2}{*}{ Fear of terrorism } & $\begin{array}{l}\text { Sometimes I'm afraid that there are terrorists among the Muslims in } \\
\text { Austria }\end{array}$ \\
\hline & The state should vigilantly observe Muslim communities \\
\hline \multirow[t]{2}{*}{ Demands of assimilation } & Islam does fit into the Western world. ${ }^{\text {a }}$ \\
\hline & Muslims have to adapt to our culture \\
\hline \multirow{2}{*}{$\begin{array}{l}\text { Highlighting } \\
\text { unequal gender roles }\end{array}$} & The headscarf is a symbol of the oppression of women \\
\hline & $\begin{array}{l}\text { Muslim girls can wear a headscarf in school, when it is part of their } \\
\text { tradition. }\end{array}$ \\
\hline \multirow[t]{3}{*}{ Discrimination } & Muslims should have the same rights as everyone in Austria. $^{\text {a }}$ \\
\hline & The practice of faith by Muslims has to be restricted \\
\hline & $\begin{array}{l}\text { We should not tolerate mosques in Austria because churches are not } \\
\text { accepted in Islamic countries }\end{array}$ \\
\hline
\end{tabular}

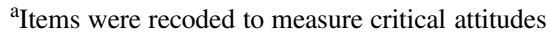

Items in bold were also used in the international study (see Pollack et al. 2010)

10 In a well-known article Bleich $(2011$, p. 1581) broadly conceptualized Islamophobia as "indiscriminate negative attitudes or emotions directed at Islam or Muslims". 
study ${ }^{11}$ in other countries (e.g. summarized in the edited volume by Pollack et al. 2014). ${ }^{12}$ This leads to the following scale to measure anti-Muslim sentiment based on certain underlying dimensions (Table 1).

The attitudinal spectrum of experiencing Muslims as a cultural enrichment vs. a cultural threat is captured with two items. Additionally, it is necessary to address explicit fears which can be traced back to the terrorism threat. The first item of this underlying dimension directly refers to fear while the second item marks the ongoing demands for strict surveillance of Muslim communities in Austria. These opinions go hand in hand with a clear demand for assimilation. It is now common in the Austrian discourse that Muslims have to strictly adapt to the host society and that cultural autonomy is only allowed to a limited extent. This is also connected to ethnocentrism and to feelings of superiority compared to Islam. We can observe arguments about accepting different gender roles, while the mainstream clearly supports the adaptation of Western gender relations. The visibility of religious symbols (especially with regard to the headscarf in the public) is often seen as pure provocation. In general, people express ambiguous feelings concerning the rights and duties of Muslims in Austrian society. This leads to the last three items measuring the guarantee of equal rights vs. opting for discrimination. On the one hand the rights of religious freedom are historically grounded in Austria (see for instance Hafez 2010 , pp. $79 \mathrm{ff}$.). Nevertheless, people often feel uncomfortable when it comes to religious practice in the public context or with regard to religious symbols. Then they use cognitive strategies (such as diffuse comparisons) to justify their discriminatory attitudes, e.g. with regard to the building of mosques in Austria.

This 11-item scale should allow us to measure the extent of anti-Muslim sentiment, to analyze gradual differences between certain dimensions, and to draw conclusions about notable differences between Austria and other European countries. A further index is subsequently constructed to treat anti-Muslim sentiment as one central outcome variable, to detect the effects of certain independent variables.

\subsection{The operationalization of sociodemographic and structural indicators}

Table 2 sheds light on the distribution of the sample. Frequency analysis (based on raw data) illustrates that there are slightly more females than males in our sample and that people from all age groups and educational levels responded to the survey. This leads to plausible household income quintiles for the Austrian population ranging from values below $1450 €$ (first quintile) to the range of middle incomes (1451-3680 $€$ ) and up to the highest income group (3681 $€$ and higher). More than $10 \%$ of the participants were born in foreign countries which reflects a slight undercoverage of the migration population in Austria (see for instance Statistics Austria 2017 , pp. $7 \mathrm{f}$.). The sample of respondents with Turkish origin or from former Yu-

\footnotetext{
11 This study is a rare example of a comprehensive cross-national approach on the topic of religious prejudice although the survey took place in 2010 .

12 This book analyzed the limits of tolerance when it comes to specific religious groups in Germany. The book is based on a cross-national survey from 2010 on the acceptance of religious diversity in five European countries.
} 
Table 2 The measurement of classical background factors in the SSÖ 2018

\begin{tabular}{|c|c|c|c|c|}
\hline Variables & Categories & $\begin{array}{l}\text { Frequencies } \\
\text { (total } n=1200 \text { ) }\end{array}$ & Percent & $\begin{array}{l}\text { Scale characteristics and } \\
\text { response categories }\end{array}$ \\
\hline \multirow[t]{3}{*}{ Gender } & Male & 556 & 46.4 & \multirow{3}{*}{$\begin{array}{l}1=\text { male }, 2=\text { female } \\
3=\text { other (treated as missing) }\end{array}$} \\
\hline & Female & 643 & 53.6 & \\
\hline & Other & 1 & - & \\
\hline \multirow[t]{5}{*}{ Age } & 18 to 29 years & 165 & 13.9 & \multirow{5}{*}{$\begin{array}{l}\text { Categorized variable, } \\
9 \text { missing values }\end{array}$} \\
\hline & $30-44$ years & 266 & 22.3 & \\
\hline & $45-59$ years & 336 & 28.2 & \\
\hline & $60-74$ years & 291 & 24.4 & \\
\hline & 75 and older & 133 & 11.2 & \\
\hline \multirow[t]{5}{*}{ Education } & Compulsory education & 150 & 12.5 & \multirow{5}{*}{$\begin{array}{l}\text { New categorized variable, } \\
3 \text { missings }\end{array}$} \\
\hline & Apprenticeship & 508 & 42.4 & \\
\hline & Middle school & 155 & 12.9 & \\
\hline & $\begin{array}{l}\text { Qualification university } \\
\text { entrance }\end{array}$ & 205 & 17.1 & \\
\hline & $\begin{array}{l}\text { Tertiary education (BA, } \\
\text { MA, PhD) }\end{array}$ & 179 & 15.0 & \\
\hline \multirow{5}{*}{$\begin{array}{l}\text { Household } \\
\text { Income }\end{array}$} & First Quintil $(0-1450 €)$ & 171 & 20.0 & \multirow{5}{*}{$\begin{array}{l}\text { In quintiles, } \\
344 \text { missings }\end{array}$} \\
\hline & $\begin{array}{l}\text { Second Quintil } \\
\text { (1451-2000) }\end{array}$ & 187 & 21.8 & \\
\hline & $\begin{array}{l}\text { Third Quintil } \\
(2001-2850)\end{array}$ & 156 & 18.2 & \\
\hline & $\begin{array}{l}\text { Fourth Quintil } \\
\text { (2851-3680) }\end{array}$ & 171 & 20.0 & \\
\hline & $\begin{array}{l}\text { Fifth Quintil (3681 und } \\
\text { mehr) }\end{array}$ & 171 & 20.0 & \\
\hline \multirow{5}{*}{$\begin{array}{l}\text { Migration } \\
\text { Back- } \\
\text { ground } \\
\text { (ref. } \\
\text { other) }\end{array}$} & Born in Austria & 1077 & 89.9 & \multirow{5}{*}{$\begin{array}{l}\text { New categorized variable, } \\
2 \text { missings }\end{array}$} \\
\hline & Born in Germany & 21 & 1.8 & \\
\hline & Born in Turkey & 22 & 1.8 & \\
\hline & $\begin{array}{l}\text { Born in Former Yu- } \\
\text { goslavia }\end{array}$ & 22 & 1.8 & \\
\hline & Other & 56 & 4.7 & \\
\hline \multirow[t]{3}{*}{ Domicile } & Countryside & 441 & 36.8 & \multirow{3}{*}{$\begin{array}{l}\text { New categorized variable, } \\
2 \text { missings }\end{array}$} \\
\hline & Middle-size cities & 372 & 31.0 & \\
\hline & Big cities, suburbs & 387 & 32.3 & \\
\hline \multirow{6}{*}{$\begin{array}{l}\text { Religious } \\
\text { denom- } \\
\text { ination }\end{array}$} & Roman katholic & 709 & 59.6 & \multirow{6}{*}{$\begin{array}{l}\text { New categorized variable, } \\
10 \text { missings }\end{array}$} \\
\hline & $\begin{array}{l}\text { Protestant (including } \\
\text { free churches) }\end{array}$ & 57 & 4.8 & \\
\hline & Christian-orthodox & 30 & 2.5 & \\
\hline & Islam & 47 & 3.9 & \\
\hline & Other & 8 & 0.7 & \\
\hline & No denomination & 339 & 28.5 & \\
\hline
\end{tabular}


goslavia is too small to derive representative conclusions. The variable of religious denomination shows that the main religious communities of Austria are also represented in the survey. The sample consists mainly of Catholics (about 60\%) and people without any denomination (around 30\%). ${ }^{13}$ Roman Catholics may be slightly underrepresented and people with no domination are overrepresented. Again, this is due to the under-coverage of people with migration backgrounds but at least more than 30 respondents declared themselves as Protestants, Muslims or Christian Orthodox. ${ }^{14}$

\subsection{Measuring individual judgements on societal integration}

Table 3 gives an overview of subjective impressions of societal functioning in Austria based on various indicators. The means for single item indicators and the scale means for concepts allow first preliminary conclusions regarding the societal embeddedness of the Austrian population. In addition to this first overview of descriptive results, indicators of the quality of the measurement (based on reliability measures or correlations) are also given. In summary, it can be stated that perceptions of social disintegration in Austrian society are not widespread at least with regard to one's personal life situation. The respondents rated themselves above average when it comes to status, and the majority of the population stated that it is quite easy to manage their household income. Social integration also seems to be widely present. Austrians report a high level of social inclusion and social recognition (measured by three items with high reliability) and generally trust their fellow citizens (measured with two classical items of personal trust which correlate moderately with each other). Nevertheless, there are signs of social destabilization with concerns being directed more towards Austrian politics and society. The majority states that they have no impact on politics anymore, and the scale mean of institutional distrust (measured with three items of sufficient reliability) is significantly higher than the scale mean of social trust. ${ }^{15}$

When it comes to future prospects most Austrians view their future in Austria in a neutral way, but their personal circumstances are seen in a brighter light (both items are moderately correlated). There is also a substantial sense of deprivation as

\footnotetext{
13 This variable is not further used in the analysis because there are high intercorrelations especially with religious practice. But religious denomination is used to exclude Muslims from the sample for the regression analysis.

14 A most recent study by Goujon et al. (2017) estimates that in 2016 about $8 \%$ of the Austrian population were Muslim and about 5\% each were Protestant or Christian orthodox (see Goujon et al. 2017, p. 13).

15 A paired samples t-test confirms that—although both features of trust are correlated $(\mathrm{r}=0.3)$ - the mean of institutional distrust is more than 0.5 higher (on a four-point scale), which leads to a highly significant discrepancy between both means $(\mathrm{t}=-21.02 ; p<0.001)$. This is mainly due to political distrust which clearly exceeds distrust in the legal or educational system.
} 
Table 3 The measurement of subjective perceptions of disintegration in the SSÖ 2018

\begin{tabular}{|c|c|c|c|c|c|}
\hline $\begin{array}{l}\text { Manifest } \\
\text { and latent } \\
\text { variables }\end{array}$ & Items & $n$ & $\begin{array}{l}\text { (Scale) } \\
\text { mean }\end{array}$ & SD & $\begin{array}{l}\text { Scale characteristics and } \\
\text { response categories }\end{array}$ \\
\hline $\begin{array}{l}\text { Subjective } \\
\text { perception } \\
\text { of Social } \\
\text { Status }\end{array}$ & $\begin{array}{l}\text { In our society are groups } \\
\text { which are on top and which } \\
\text { are more at the bottom. } \\
\text { When you think of yourself } \\
\text { where would you position } \\
\text { yourself }\end{array}$ & 1171 & 5.82 & 1.45 & $\begin{array}{l}\text { Single item (Scale from } \\
1=\text { at the bottom to } 10=\text { on } \\
\text { the top) }\end{array}$ \\
\hline $\begin{array}{l}\text { Dealing with } \\
\text { household } \\
\text { income }\end{array}$ & $\begin{array}{l}\text { How easy or difficult is it to } \\
\text { deal with income? }\end{array}$ & 1188 & 2.60 & 1.00 & $\begin{array}{l}\text { Single item, five-point } \\
\text { scale } \\
(1=\text { very easy to } 5=\text { very } \\
\text { difficult })\end{array}$ \\
\hline $\begin{array}{l}\text { Lack of } \\
\text { political } \\
\text { efficacy (no } \\
\text { impact on } \\
\text { government) }\end{array}$ & $\begin{array}{l}\text { People like me have no } \\
\text { impact on government deci- } \\
\text { sions }\end{array}$ & 1191 & 3.44 & 1.25 & $\begin{array}{l}\text { Single item, five-point } \\
\text { scale }(1=\text { not agree to } \\
5=\text { fully agree })\end{array}$ \\
\hline $\begin{array}{l}\text { Social dis- } \\
\text { trust }\end{array}$ & $\begin{array}{l}\text { Most people can vs. cannot } \\
\text { be trusted } \\
\text { Most people try to be fair vs. } \\
\text { try to get advantage }\end{array}$ & 1169 & 2.15 & 0.61 & $\begin{array}{l}\text { Mean value on both items } \\
(r=0.24)(1=\text { left pole to } \\
4=\text { right pole })\end{array}$ \\
\hline $\begin{array}{l}\text { Perceptions } \\
\text { of inclusion }\end{array}$ & $\begin{array}{l}\text { Last four weeks (missing } \\
\text { contacts) } \\
\text { Last four weeks (feeling } \\
\text { lonely) } \\
\text { Last four weeks (feeling } \\
\text { excluded) }\end{array}$ & 1196 & 4.60 & 0.69 & $\begin{array}{l}\text { Mean values on three items } \\
(\alpha=0.86)(1=\text { very often to } \\
5=\text { never, recoded })\end{array}$ \\
\hline $\begin{array}{l}\text { Institutional } \\
\text { distrust }\end{array}$ & $\begin{array}{l}\text { Distrust in parliament } \\
\text { Distrust in courts and in the } \\
\text { legal system } \\
\text { Distrust in schools and edu- } \\
\text { cational system }\end{array}$ & 1142 & 2.66 & 0.43 & $\begin{array}{l}\text { Mean values on three items } \\
(\alpha=0.70) \\
(1=\text { complete trust to } \\
5=\text { no trust })\end{array}$ \\
\hline $\begin{array}{l}\text { Fears of so- } \\
\text { cial decline }\end{array}$ & $\begin{array}{l}\text { Your personal life situation } \\
\text { will get worse? } \\
\text { The situation in Austria will } \\
\text { get worse? }\end{array}$ & 1131 & 2.92 & 0.68 & $\begin{array}{l}\text { Mean value on both items } \\
(\mathrm{r}=0.39)(1=\text { improve to } \\
5=\text { will get worse })\end{array}$ \\
\hline $\begin{array}{l}\text { Feelings of } \\
\text { being under- } \\
\text { privileged }\end{array}$ & $\begin{array}{l}\text { Do you feel disadvantaged in } \\
\text { society? } \\
\text { Do you get an unequal share } \\
\text { of income? }\end{array}$ & 1131 & -0.20 & 0.45 & $\begin{array}{l}\text { Mean value on recoded } \\
\text { items }(\mathrm{r}=0.48) \\
(-1=\text { disadvantaged, un- } \\
\text { equal share, } \\
0=\text { equal share, } \\
1=\text { privileged, more than } \\
\text { equal share })\end{array}$ \\
\hline
\end{tabular}


the majority of the population report that they receive an unequal share of income or are feeling disadvantaged in society (both items are rather strongly correlated). ${ }^{16}$

\subsection{The operationalization of religious beliefs, attitudes and practices}

A particular advantage of this study is the detailed measurement of religious beliefs, practices and attitudes. This is due to the religion module of the 2018 ISSP Survey, which was included with the SSÖ $2018^{17}$ (Table 4).

It was possible to provide a sophisticated measurement about Christian beliefs (in life after death, heaven and hell, and in miracles) and in conventional religious practice (frequency of church attendance, praying and church activities). Besides these classical forms of religious practice, there is a scale for spiritual activities which measures whether people read spiritual books or practiced meditation, yoga or alternative healing methods during the last year. There is also a factor pointing to superstition which refers to people believing in fortune-tellers, miracle healers, lucky charms or in astrology. It was also possible to include two aspects of religious attitudes. The first items attempt to demonstrate the desire to place religion more prominently in society (e.g. trusting in the church, giving religion more power, etc.). It was also possible to capture viewpoints on the role of religion with two additional items (religion is useful for finding friendships and provides solace in hard times).

Although all concepts are measured with high reliability, the first three aspects of religious attitudes and practice are somewhat interrelated. A principal component analysis (promax rotation) revealed no clear discrimination among those items measuring conventional religious beliefs, aspects of conventional religious practice, and assessing the role of religion in society. On the other hand, the other concepts pointing to an alternative form of religiosity (making sense out of religion, superstition and spirituality) could be clearly distinguished from each other. ${ }^{18}$

Reviewing the mean values of Austrian citizens with regard to these religious aspects highlights that the majority of the people tend to follow a rather secular orientation. This is clearly visible in the mean reflecting core Christian beliefs, which indicates that the majority of Austrians do not belief in heaven or hell, but a higher proportion still believes in life after death or in miracles (not in the table). The indicator of religious practice also shows that most of the respondents do not regularly pray, go to church or participate in religious activities anymore.

\footnotetext{
16 A principal component analysis (with promax rotation) demonstrates an interesting structure of interrelations of all these concepts on societal wellbeing. Two factors at the individual level (societal inclusion) and at the system level (institutional dissatisfaction) could be clearly distinguished. Additionally, aspects referring to economic disadvantages (regarding positional integration, income or perceiving disadvantages) and fears of social and cultural decline (social distrust and future pessimism) could be extracted and are only weakly correlated. It was decided to include all concepts independently in the main regression analysis (see Sect. 5.2) to guarantee more fine-tuned results.

17 This module consists of more than 50 indicators and is repeated every 10 years to identify trends in religiosity in the participating countries (see http://w.issp.org/menu-top/home/, retrieved on 09.02.2020).

18 It was again decided to treat all concepts separately to provide a differentiated analysis of all potential religious influences on anti-Muslim sentiment. This is also possible because multicollinearity is not problematic in the regression analysis. All tolerance values are well below 0.4 which is seen as sufficient in regression analysis to provide plausible estimates of effect sizes (vgl. Urban and Mayerl 2011, p. 232).
} 
Table 4 The measurement of religious beliefs in the SSÖ 2018

\begin{tabular}{|c|c|c|c|c|c|}
\hline $\begin{array}{l}\text { Manifest } \\
\text { and latent } \\
\text { variables }\end{array}$ & Items & $n$ & $\begin{array}{l}\text { (Scale) } \\
\text { mean }\end{array}$ & SD & $\begin{array}{l}\text { Scale characteristics and } \\
\text { response categories }\end{array}$ \\
\hline $\begin{array}{l}\text { Less } \\
\text { religious } \\
\text { beliefs }\end{array}$ & $\begin{array}{l}\text { Belief in life after death } \\
\text { Belief in heaven } \\
\text { Belief in hell } \\
\text { Belief in miracles }\end{array}$ & 1019 & 2.65 & 0.95 & $\begin{array}{l}\text { Mean values on four items } \\
(\alpha=0.88) \\
(1=\text { yes, definitely to } \\
4=\text { definitely not })\end{array}$ \\
\hline $\begin{array}{l}\text { Placing } \\
\text { religion } \\
\text { promi- } \\
\text { nently in } \\
\text { society }\end{array}$ & $\begin{array}{l}\text { Trust in church/religious orga- } \\
\text { nizations (recoded) } \\
\text { Too much trust in science, less } \\
\text { in religion (recoded) } \\
\text { Religions provoke conflicts, not } \\
\text { peace } \\
\text { Churches have too much power } \\
\text { in Austria }\end{array}$ & 999 & 2.32 & 0.75 & $\begin{array}{l}\text { Mean values on four items } \\
(\alpha=0.69) \\
(1=\text { no trust to } 5=\text { full } \\
\text { trust; } 1=\text { fully agree to } \\
5=\text { not agree; } 1=\text { too much } \\
\text { power to } 5=\text { too little } \\
\text { power })\end{array}$ \\
\hline $\begin{array}{l}\text { Religious } \\
\text { practice }\end{array}$ & $\begin{array}{l}\text { Frequency church attendance } \\
\text { Frequency praying } \\
\text { Frequency church activities }\end{array}$ & 1118 & 2.49 & 1.15 & $\begin{array}{l}\text { Mean values on three } \\
\text { items }(\alpha=0.79)(1=\text { never } \\
\text { to } 5=\text { weekly, recoded })\end{array}$ \\
\hline $\begin{array}{l}\text { Sense of } \\
\text { religion }\end{array}$ & $\begin{array}{l}\text { Religion is useful for finding } \\
\text { friendships } \\
\text { Religion is useful for offering } \\
\text { solace in hard times }\end{array}$ & 1.065 & 3.54 & 1.08 & $\begin{array}{l}\text { Mean values on two items } \\
(\mathrm{r}=0.62)(1=\text { not agree to } \\
5=\text { fully agree })\end{array}$ \\
\hline Superstition & $\begin{array}{l}\text { Lucky charms sometimes actu- } \\
\text { ally bring luck } \\
\text { Some fortune-tellers can pre- } \\
\text { dict the future } \\
\text { Some miracle healers have } \\
\text { supernatural powers } \\
\text { The signs of the zodiac have an } \\
\text { influence on life }\end{array}$ & 1023 & 2.08 & 0.79 & $\begin{array}{l}\text { Mean values on four items } \\
(\alpha=0.83) \\
(1=\text { not agree to } 5=\text { fully } \\
\text { agree })\end{array}$ \\
\hline $\begin{array}{l}\text { Susceptibility } \\
\text { for spiri- } \\
\text { tuality and } \\
\text { esoterism }\end{array}$ & $\begin{array}{l}\text { Last } 12 \text { months: meditation } \\
\text { Last } 12 \text { months: doing yoga, tai } \\
\text { chi, qigong } \\
\text { Last } 12 \text { months: using alterna- } \\
\text { tive healing methods } \\
\text { Last } 12 \text { months: reading spiri- } \\
\text { tual/esoteric books }\end{array}$ & 1175 & 1.52 & 0.57 & $\begin{array}{l}\text { Mean values on four items } \\
(\alpha=0.72) \\
(1=\text { no never to } 3=\text { at least } \\
\text { last year) }\end{array}$ \\
\hline
\end{tabular}

This may lead to a critical view of religion in society, where the majority votes for a separation of church and state. Nevertheless, the deeper sense of religion still has value for considerable parts of the population. Many people seem to be searching for meaning in life, but only a minority of Austrians seems to be susceptible to superstition, or active in various forms of spiritual practice.

The following analysis presents the results in the order of the main hypotheses of the study. The analysis of the dependent variable (anti-Muslim sentiment) refers to hypotheses 1-3 but is restricted to scale evaluation and to a descriptive analysis. The main assumptions (hypotheses 4 to 15) regarding the drivers of critical attitudes towards Muslims are tested by a sequential multiple OLS-regression. While the first model includes classical control variables (sociodemographic and socio-structural background variables), the second model integrates factors representing economic 
discontent or perceiving social disintegration. The third model breaks new ground in research because for the first time it uses a comprehensive conception of religious beliefs, practices and attitudes to contribute to a more substantial explanation of anti-Muslim sentiment. ${ }^{19}$

\section{Empirical results}

\subsection{The extent of anti-Muslim sentiment in Austrian society}

To give a clear picture of the extent of anti-Muslim sentiment in Austria, all indicators were dichotomized to provide an illustration of the agreement rates ("agree" and "rather agree") of the Austrian population. Fig. 1 illustrates the agreement to all statements referring to the whole sample.

The graph clearly shows that critical attitudes towards Muslims are highly relevant within Austria. Nearly 90\% of the respondents hold the position that Muslims have to adapt to Austrian culture and about $80 \%$ advocate a stronger observation of Islamic communities. In addition, almost three quarters of the population believe that Islam does not enrich the culture and $60 \%$ fear that terrorists are among the Muslims in Austria. Some items clearly point to a high level of ethnocentrism and feelings of superiority. Almost $70 \%$ of Austrians are convinced that Islam does not fit into the Western world, that the headscarf indicates strong gender hierarchies in Islam and that the headscarf for girls should be banned in schools. With regard to issues of discrimination, however, the Austrian population is divided. About $50 \%$ of the population are of the opinion that mosques should not be built in Austria because churches in Muslim countries are not accepted either. A slight majority of the population also believes that the Muslim practice of faith should at least be more strongly regulated, with about $45 \%$ explicitly advocating restricting the rights of Muslims.

An insight into certain underlying arguments concerning Muslims may provide additional empirical value about slight differences among the different dimensions. Reviewing Fig. 2 it is clear that demands for assimilation are particularly widespread within Austria, as well as the perception and criticism of unequal gender roles.

It also seems that the liberal spectrum of Austrian society fears a rejection of Western emancipatory achievements and often implicitly views Muslims as backward, and unwilling to adapt to Western gender roles. September 11th is still often seen as a signal event (Heitmeyer 2012) of a worldwide criticism of Islam and the numerous attacks in Europe during the last decades have also left its mark on Austrian society. Fear of terrorism and the demand to vigilantly observe Muslims in Austria is expressed by large parts of the population. This may also be the reason why people with a Muslim background are mainly perceived as a cultural threat for Austria and not as providing cultural enrichment. Nevertheless, a small majority of Austrians still opt for religious freedom and equal rights, although there

19 The multiple regression analysis is done with a multiple imputation procedure to control for missing values (without weighting and excluding people with Islamic faith from the sample). 


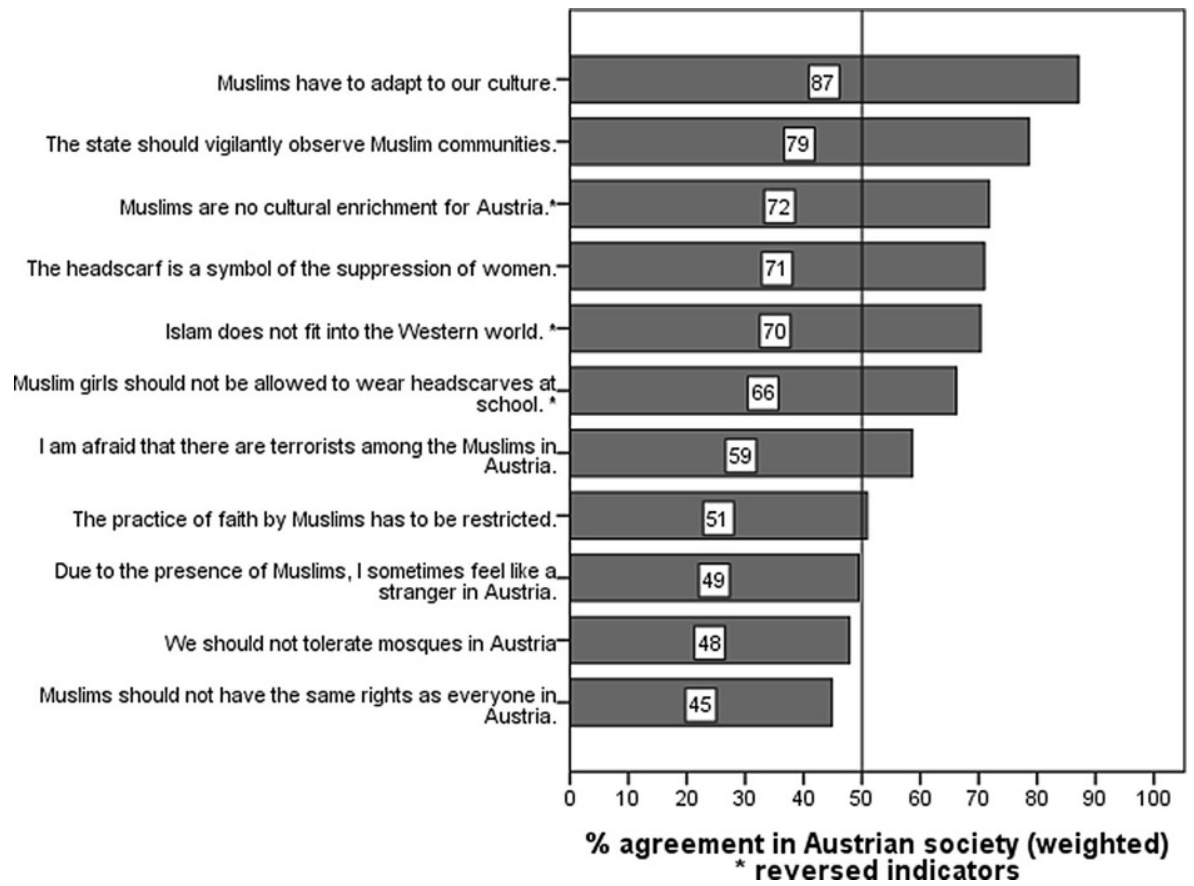

Fig. 1 Agreement rates with regard to the 11 items measuring anti-Muslim sentiment

are considerable parts of the population who openly opt for discrimination against Muslims.

Although the impressions of Austrians towards Islam are predominantly negative, which was clearly visible in the two figures, it is worthwhile to compare the attitudes of Austrian citizens to those in other countries. The only way to compare the Austrian results with other European countries is to refer to the cross-national survey on recognition and acceptance of religious pluralism in Europe (e.g. Pollack et al. 2014 for Germany). This survey provided a sophisticated measurement of attitudes towards Muslims based on representative samples in five countries (Germany, Denmark, France, the Netherlands and Portugal) in 2010. At least five items were measured in an identical way, so it is possible to compare the Austrian opinions with the attitudes of those in other countries.

When we look at Fig. 3, it can clearly be seen that the critical attitudes are in general rather similar in Austria, Germany, the Netherlands and France. In all countries (including Denmark) more than $80 \%$ of the population are in favor of assimilation and more than two thirds clearly express their opinion that Islam does not fit into the Western world. With regard to other indicators, the Danish tend to be less critical particularly when it comes to viewing Muslims as a cultural threat and restricting their practice of faith. It is clearly observable that the Portuguese are far more tolerant towards Muslims. This is especially seen with regard to the last three indicators. A strong majority in Portugal see Muslims as a cultural enrichment, they 


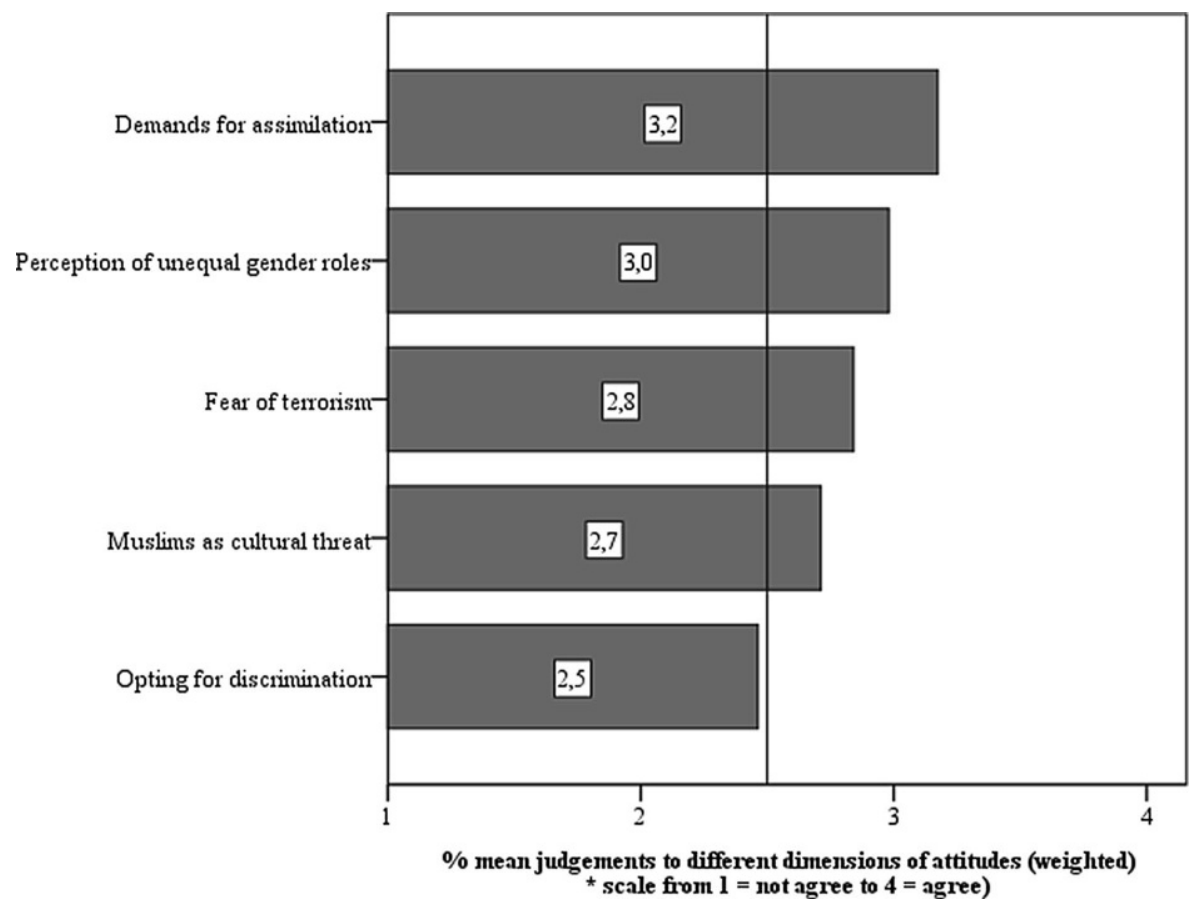

Fig. 2 Agreement rates with regard to the underlying dimensions

are clearly against restricting their practice of faith, and most Portuguese do not feel like strangers in their country.

In general, the Austrians and the Germans tend to be the most critical concerning Muslims, closely followed by the Dutch and the French. Only Austrians and Germans see predominantly no cultural enrichment by Muslims, with people in Eastern Germany being slightly more critical than Western Germany. People in France are in the lead in wanting to restrict the religious practice of Muslims, while the majority of people in the Netherlands sometimes feel like a stranger in their own country. Overall, Austrian attitudes are congruent with those in other European countries, assuming that attitudes towards Muslims remain relatively stable.

Empirically it was not possible to distinguish between different facets of Islamophobia although slight differences in the agreement rates are obvious. A principal component analysis (with Varimax rotation) clearly revealed that all anti-Muslim sentiment forms only a single factor. This factor is able to explain more than $50 \%$ of the variance of all items. ${ }^{20}$ The high reliability of the scale (Cronbach $\alpha=0.92$ ) indicates that it is possible to measure one general syndrome of critical attitudes towards Muslims with all items. This index on anti-Muslim sentiment was further used as the

20 Additionally, all items belonging to those factors exert a sufficient factor loading $(>0.6)$ which additionally confirms that the population is either critical or open towards Muslims and that they do not distinguish between certain facets of the construct. 


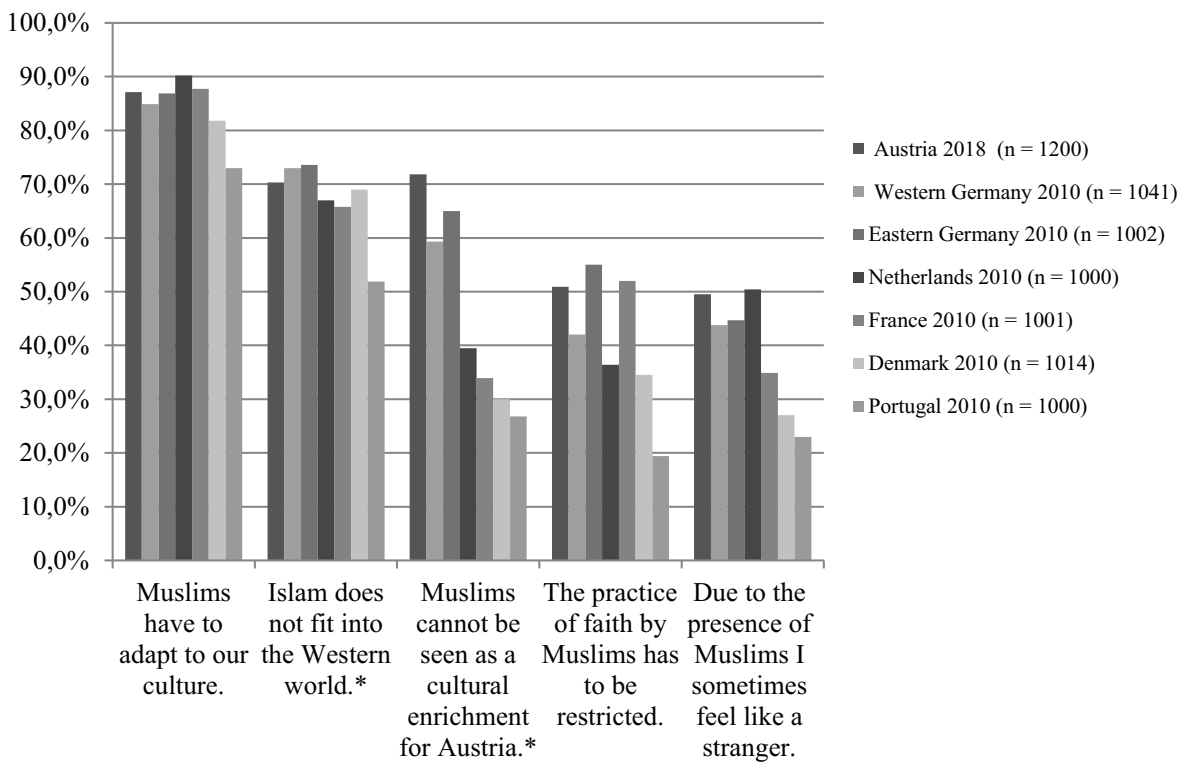

Fig. 3 Attitudes towards Muslims in Austria 2018 and other European countries based on the survey 2010

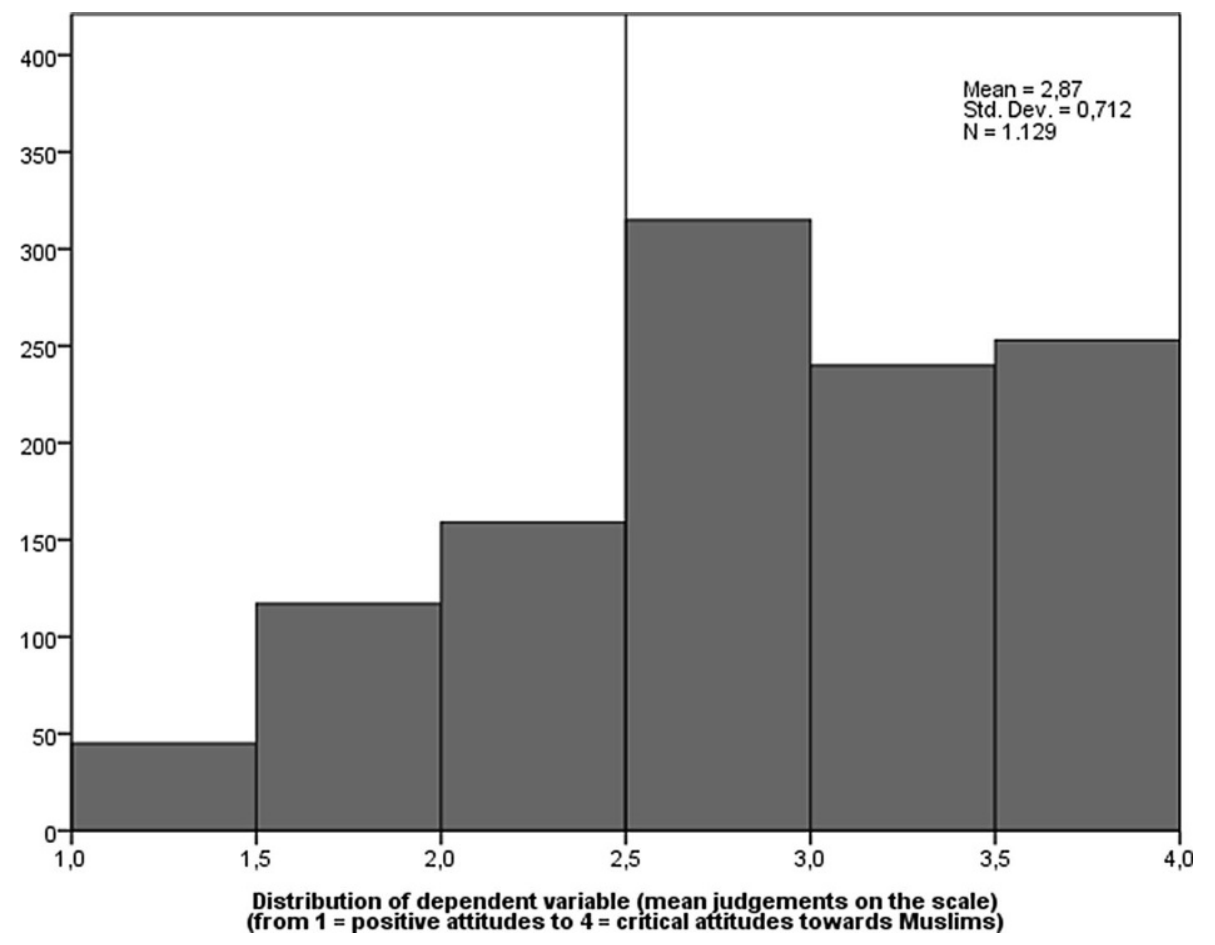

Fig. 4 The distribution of the dependent variable "anti-Muslim sentiment" in the study 
central dependent variable in the study. ${ }^{21}$ In line with the descriptive analysis it has a skewed distribution, because the majority of the population demonstrates a high level of skepticism towards Muslims (mean $=2.87$ on a four-point scale) (Fig. 4).

\subsection{The antecedents of anti-Muslim sentiment}

To detect the main explanatory variables, which are responsible for critical views towards Muslims, a hierarchical regression was computed. The general index of anti-Muslim sentiment was used as a dependent variable and various predictors were introduced in three stages. The first model comprises mainly sociodemographic and socio-structural background indicators, the second model additionally includes indicators of societal dissatisfaction and the third model adds the newly established concepts on religious beliefs, practices and attitudes. It was necessary to run a few control mechanisms to guarantee a stable regression model. ${ }^{22}$ In Fig. 5 all three models are illustrated. ${ }^{23}$

It is possible to explain $13 \%$ of the variance on anti-Muslim sentiment with the first model of background variables. The second model-including aspects of societal integration-leads to a slight increase (19\% explained variance), while the third model (consisting of religious factors) leads to a considerable increase in effect size (27.5\% explained variance). The first model refers to classical predictors which have often been proven to have significant impact on prejudice. Regarding age, five groups were used to detect potentially non-linear effects. It seems that compared to the young group (aged 18-29 years) all respondents and especially the elderly (older than 75 years) react more critically towards Muslims. The educational effect shows that people with higher education clearly exhibit less prejudice. This effect remains consistent across all three models, although people with completed apprenticeships seem to be more susceptible to prejudice. This result is also confirmed when we turn our attention to income. People from the lower middle classes (the second

\footnotetext{
21 Due to high intercorrelation of all items, it was considered sufficient to have respondents' viewpoints on at least three items in order to be part of the scale. This strategy could increase the sample size because 1183 participants (out of 1200) gave sufficient answers to the items. In the regression analysis the participants with Islamic denomination were excluded from the sample to give an adequate picture of the drivers of hostility towards Muslims in the majority population.

22 All indicators were dichotomized or based on indices to fulfil the statistical requirements of a multiple OLS-regression. Due to the multiplicity of indicators and due to a high number of missing values (especially when it comes to income, see Table 1) multiple imputation was chosen to achieve more stable coefficients. This was done in SPSS 18 implementing the following procedures: In a first step, 20 new datasets were constructed with a full imputation of missing values. This is done automatically by SPSS with classical imputation procedures for categorial and metric variables. In a second step, the regression analysis was repeated 20 times. The main added value with the strategy of multiple imputation is achieved with pooled coefficients based on the average of the 20 copies of the data file. It is not possible to run a pooled analysis in SPSS but there are some data management strategies to create this dataset (see this video for illustration, https://youtu.be/zftIxv532hE). The multiple imputation procedure is not directly replicable, but it yielded roughly the same results as a regression done with pairwise deletion. This is a good sign that all coefficients are stable and not susceptible to missing values (for further explanation on the multiple imputation procedures in SPSS see Urban et al. 2016).

23 Significant effects $(p<0.05)$ are marked in grey, very significant coefficients $(p<0.01)$ are marked in dark grey and highly significant explanatory variables $(p<0.001)$ are shaded nearly black.
} 


\begin{tabular}{|c|c|c|c|c|c|c|c|}
\hline \multirow{3}{*}{ Variables } & \multirow{3}{*}{ Categories } & \multicolumn{6}{|c|}{ Dependent variable: Critical attitudes towards Muslims } \\
\hline & & \multicolumn{2}{|c|}{$\begin{array}{l}\text { Model } 1 \text { (sociodemographic } \\
\text { and structural factors) } \\
\text { Corr } \mathrm{r}^{2}=13.3 \%\end{array}$} & \multicolumn{2}{|c|}{ 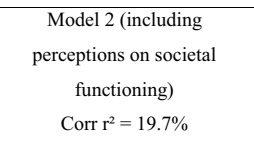 } & \multicolumn{2}{|c|}{$\begin{array}{c}\text { Model } 3 \text { (including aspects of } \\
\text { religion) } \\
\text { Corr r } \mathrm{r}^{2}=27.5 \%\end{array}$} \\
\hline & & $\begin{array}{r}\text { Unstandardized } \\
\text { Coefficients }\end{array}$ & $\begin{array}{r}\text { t-values } \\
\text { and } \\
\text { significance }\end{array}$ & $\begin{array}{r}\text { Unstandardized } \\
\text { Coefficients }\end{array}$ & $\begin{array}{r}\text { t-values } \\
\text { and } \\
\text { significance }\end{array}$ & $\begin{array}{r}\text { Unstandardized } \\
\text { Coefficients }\end{array}$ & \begin{tabular}{|r} 
t-values \\
and \\
significance
\end{tabular} \\
\hline Constant & & 2.21 & & 1.04 & & 2.23 & \\
\hline \multirow{4}{*}{$\begin{array}{l}\text { Age (ref. } 18 \text { to } \\
29 \text { years) }\end{array}$} & $30-44$ years & $0.19(0.11)$ & $2.68 * *$ & $0.13(0.08)$ & 1.91 & $0.13(0.08)$ & $2.00^{*}$ \\
\hline & $45-59$ years & $0.15(0.10)$ & $2.31^{*}$ & $0.13(0.08)$ & $2.01 *$ & $0.15(0.10)$ & $2.47^{*}$ \\
\hline & $60-74$ years & $0.14(0.09)$ & $2.04 *$ & $0.15(0.09)$ & $2.26^{*}$ & $0.16(0.10)$ & $2.50^{*}$ \\
\hline & 75 and older & $0.34(0.16)$ & $4.19 * * *$ & $0.42(0.19)$ & $5.20 * * *$ & $0.42(0.19)$ & $5.30 * * *$ \\
\hline \multirow{4}{*}{$\begin{array}{l}\text { Education } \\
\text { (ref. tertiary } \\
\text { education) }\end{array}$} & Compulsory education & $0.49(0.22)$ & $6.08 * * *$ & $0.36(0.16)$ & $4.37^{* * *}$ & $0.30(0.13)$ & $3.68^{* * *}$ \\
\hline & Apprenticeship & $0.50(0.35)$ & $8.18 * * *$ & $0.37(0.26)$ & $6.03 * * *$ & $0.28(0.20)$ & $4.71 * * *$ \\
\hline & Middle school & $0.35(0.17)$ & $4.73 * * *$ & $0.26(0.12)$ & $3.48^{* *}$ & $0.17(0.08)$ & $2.44 *$ \\
\hline & $\begin{array}{l}\text { Qualification for university } \\
\text { entrance }\end{array}$ & $0.19(0.10)$ & $2.75^{* *}$ & $0.15(0.08)$ & $2.18^{*}$ & $0.11(0.06)$ & 1.62 \\
\hline \multirow{3}{*}{$\begin{array}{l}\text { Household } \\
\text { Income (ref. }\end{array}$} & First Quintile & $-0.01(0.00)$ & -0.13 & $-0.01(-0.01)$ & -0.30 & $-0.04(-0.02)$ & -0.86 \\
\hline & Second Quintile & $0.21(0.10)$ & $3.52 * * *$ & $0.19(0.10)$ & $3.38^{* *}$ & $0.12(0.06)$ & $2.18^{*}$ \\
\hline & Third Quintile & $0.10(0.05)$ & 1.79 & $0.08(0.04)$ & 1.47 & $0.06(0.03)$ & 1.08 \\
\hline \multirow{4}{*}{$\begin{array}{l}\text { highest } \\
\text { quintile) } \\
\text { Migration } \\
\text { Background } \\
\text { (ref. other) }\end{array}$} & Fourth Quintile & $0.05(0.02)$ & 0.86 & $0.08(0.04)$ & 1.39 & $0.07(0.04)$ & 1.42 \\
\hline & Born in Austria & $-0.06(-0.02)$ & -0.56 & $-0.03(-0.01)$ & -0.34 & $-0.14(-0.05)$ & -1.49 \\
\hline & Born in Germany & $-0.39(-0.07)$ & $-2.25^{*}$ & $-0.38(-0.07)$ & $-2.29 *$ & $-0.41(-0.08)$ & $-2.60^{*}$ \\
\hline & Born in Former Yugoslavia & $-0.14(-0.03)$ & -0.81 & $-0.12(-0.02)$ & -0.72 & $-0.22(-0.04)$ & -1.31 \\
\hline \multirow{2}{*}{$\begin{array}{l}\text { Domicile (ref. } \\
\text { big cities or } \\
\text { suburbs) }\end{array}$} & Countryside & $0.16(0.11)$ & $3.26^{* *}$ & $0.16(0.11)$ & $3.35^{* *}$ & $0.14(0.10)$ & $3.09 * *$ \\
\hline & Middle-size cities & $0.21(0.14)$ & $4.12 * * *$ & $0.19(0.12)$ & $3.67^{* * *}$ & $0.16(0.10)$ & $3.27 * *$ \\
\hline \multicolumn{2}{|c|}{ Subjective perception of social status } & & & $0.03(0.06)$ & 1.93 & $0.03(0.06)$ & 1.83 \\
\hline \multicolumn{2}{|c|}{ Difficulties with household income } & & & $-0.06(-0.09)$ & $-2.71 * *$ & $-0.04(-0.06)$ & -1.90 \\
\hline \multicolumn{2}{|c|}{$\begin{array}{l}\text { Lack of political efficacy (no impact on } \\
\text { government) }\end{array}$} & & & $0.07(0.12)$ & $4.02 * * *$ & $0.05(0.09)$ & $3.42 * *$ \\
\hline \multicolumn{2}{|l|}{ Social distrust } & & & $0.17(0.14)$ & $4.61^{* * *}$ & $0.14(0.12)$ & $4.10^{* * *}$ \\
\hline \multicolumn{2}{|c|}{ Perceptions of inclusion } & & & $0.09(0.09)$ & $2.97^{* *}$ & $0.06(0.06)$ & $2.12 *$ \\
\hline \multicolumn{2}{|c|}{ Institutional distrust } & & & $0.08(0.08)$ & $2.91^{* *}$ & $0.08(0.08)$ & $2.92 * *$ \\
\hline \multicolumn{2}{|c|}{ Fears of social decline } & & & $0.02(0.02)$ & 0.70 & $0.03(0.02)$ & 0.78 \\
\hline \multicolumn{2}{|c|}{ Feelings of deprivation } & & & $-0.08(-0.05)$ & -1.51 & $-0.02(-0,01)$ & -0.44 \\
\hline \multicolumn{2}{|c|}{ Less religious beliefs } & & & & & $-0.07(-0,09)$ & $-2.40^{*}$ \\
\hline \multicolumn{2}{|c|}{ Placing religion prominently in society } & & & & & $-0.27(-0.24)$ & $-6.75 * * *$ \\
\hline \multicolumn{2}{|c|}{ Religious practice } & & & & & $0.09(0.14)$ & $3.50^{* * *}$ \\
\hline \multicolumn{2}{|l|}{ Sense of religion } & & & & & $-0.07(-0.11)$ & $-3.60^{* * *}$ \\
\hline \multicolumn{2}{|l|}{ Superstition } & & & & & $0.14(0.15)$ & $4.76^{* * *}$ \\
\hline \multicolumn{2}{|c|}{ Susceptibility for spirituality and esoterism } & & & & & $-0.22(-0.18)$ & $-5.99 * * *$ \\
\hline
\end{tabular}

Fig. 5 OLS-sequential regression to explore the drivers of anti-Muslim sentiment. Note: Unstandardized coefficients are illustrated (standardized in brackets), additionally t-values and significance levels are reported (from $p<0.1^{+}$to $p<0.001 * * *$ ) 
and third quintile of household income) are more inclined to hold critical views of Muslims. A clear and stable effect also arises regarding domicile, with people in urban areas being more tolerant towards Muslims than people in smaller cities or in the countryside. When it comes to migration background, it is of interest that German immigrants tend to react with more tolerance towards Muslims compared to other immigrant groups.

When we focus on the second model, the perceptions of social disintegration contribute to the explanation of anti-Muslim sentiment, but only to a limited extent. They can be seen as mediators with regard to the first level, although there are only a few substantial changes in the effect size of the predictors. Controlling for aspects of social integration leads to lower age effects, in particular the positive effect of middle age groups (30-44 years) loses importance and becomes insignificant. Additionally, people with higher qualifications (middle school or high school diploma) are not as critical with regard to Muslims when economic and cultural insecurities are taken into account.

Interestingly, economic factors are not specifically relevant to explaining antiMuslim sentiment. The subjective evaluation of one's position in society exerts no influence and difficulties managing household income leads to a very small increase in critical attitudes towards immigrants. Also, indicators of political dissatisfaction (lack of political efficacy and institutional distrust) exert a significant influence on anti-Muslim sentiment, but this effect is lower than the impact of social distrust. In general, it is surprising that all aspects referring to fear of social decline or feelings of deprivation have no impact on the outcome variable. The effect of societal inclusion is again very weak, but it runs in the opposite direction. This means that people who feel socially included exhibit slightly higher levels of prejudice compared to those people with a lack of embeddedness in society.

Contrary to those aspects, all variables concerning religion have a significant impact on anti-Muslim sentiment, but the directions of influence are different. On the one hand, conventional Christian beliefs and religious practices exert a negative impact on the view of Muslims, while attitudes favoring the role of religion lead to more tolerance. Additionally, a spiritual way of living and searching for a deeper meaning in life through religion provokes a clear decrease in anti-Muslim sentiment, while superstition is again connected with more critical attitudes towards Muslims. Interestingly, nearly all of the predictors, which were significant at the first two levels of the model, remain relevant in the last model. So it seems that religious aspects are able to provide additional explanatory power to estimate the extent of anti-Muslim sentiment in Austrian society.

\section{Summary and discussion of the results}

The empirical results concerning the extent of anti-Muslim sentiment and the main antecedents to explain those specific forms of prejudice clearly showed that it is necessary to deal with sophisticated scales and with elaborate concepts to shed light on issues which are still neglected in research. This article focused on various potential dimensions underlying classical argumentation patterns concerning Muslims (see in 
detail Aschauer 2017) and incorporates them in a sophisticated scale to measure widespread anti-Muslim sentiment. Finally, it was not possible to distinguish certain facets of anti-Muslim sentiment because all indicators are highly correlated. This indicates that various statements can be subsumed under one superordinate factor of a critical vs. positive attitude towards Muslims (confirmation of hypothesis 1). From a methodological standpoint we can state that a few general indicators on attitudes towards Muslims are sufficient in large-scale surveys to get a first insight at the empirical importance of the phenomenon.

Additionally, it seems that attitudes towards Muslims can hardly be differentiated from general opinions towards immigrants (see Helbling 2012, pp. 10f.). The results of investigating the antecedents of anti-Muslim sentiment suggest that people in Europe (and especially in countries with a large Muslim immigrant population) may directly associate immigrants with Muslims and thus make no clear distinction between a general prejudice towards ethnic groups and specific fears regarding Muslims. Thus, it is still an open question (see particularly Helbling 2010) of whether there is an empirical distinction between ethnic prejudice in general and anti-Muslim sentiment in particular. This survey, solely focusing on attitudes towards Muslims, cannot solve this puzzle but can at least provide further insights into the argumentation patterns and certain drivers of prejudice. When it comes to the nature of antiMuslim sentiment in Austria this study shows that there is at least a slight distinction between demands for assimilation (which are shared by the majority of the citizens), impressions of backwardness (which are often mentioned with regard to gender roles) and fears of terrorism (together with demands for surveillance) which are also quite widespread in Austria. These impressions can further provoke discriminatory attitudes which are shared by significant parts of the population. The results for Austria show that nearly half of the population shares the opinion that the practice of faith has to be restricted, that mosques should not be tolerated and that Muslims should not have the same rights as everybody (confirmation of hypothesis 2). The comparison of the Austrian results with a cross-national survey in 2010 — where at least some identical indicators have been used-clearly revealed that Austria is not really exceptional in terms of attitudes, although critical attitudes are somewhat more pronounced compared to other countries (only partly confirming hypothesis 3). There is a significant time lag (2010-2018) between the two surveys which makes the comparisons of attitudes rather vague. In 2010, the discourse on Muslim immigrants had already intensified in Germany (due to Sarrazin's book in 2010) as well as in Denmark (based on the conflict concerning the Mohammed cartoons, e.g. Olesen 2007). Also, in the Netherlands the ongoing discourse on Muslim integration in the last decades has increased polarization tendencies in society (e.g. Entzinger 2014). It can be assumed that Muslim immigration is still a hot topic in France (due to recent terrorist attacks), and in Germany and Austria (due to the refugee situation). But perhaps in Denmark and the Netherlands today Muslim migration and integration is no longer the most pressing issue, which may go hand in hand with a slight decrease in negative attitudes. In this respect, it is also remarkable that Portugal ranks the lowest with regard to all indicators, despite major economic problems during recent years. This strengthens the thesis that public discourse is 
especially relevant in explaining certain forms of prejudice (e.g. Semyonov et al. 2006) but these impact factors are hard to measure in population surveys.

The sophisticated analysis of critical attitudes towards Muslims in Austria combined with a comprehensive analysis of the dynamics of prejudice formation with a special focus on religion represents a novelty in Austrian research. But before coming to potential emerging predictors in the research on prejudice, the first research aim was to replicate classical findings in ethnocentrism research because most studies (e.g. Stolz 2005; Kühnel and Leibold 2007; Strabac and Listhaug 2008) argue that similar factors equally explain xenophobia and Islamophobia. Also, in this study it could be found that elderly people tend to react with more criticism (confirmation of hypothesis 4). The educational cleavage (e.g. Coenders and Scheepers 2003; Meeusen et al. 2013), which is always a stable factor in the research on ethnic prejudice, seems to be equally relevant when it comes to anti-Muslim sentiment (confirmation of hypothesis 5). Besides education, it is interesting that income (confirmation of hypothesis 6) exerts an additional effect but the impact is stronger in the second and third household income segments. The slightly stronger resentments in those vulnerable middle classes of society deserve further attention in future research. Up to now most results from qualitative studies show that it is exactly those groups who fear precarity and social decline, that perceive higher levels of injustice and are susceptible to right-wing populists and their scapegoating of Muslims (e.g. Dörre et al. 2006; Flecker and Kirschenhofer 2007).

Domicile (confirmation of hypothesis 7) additionally contributes to the explanation of anti-Muslim sentiment, which strengthens the thesis of a strong urban-rural polarization in Austrian society (e.g. Bacher 2017). The small effect of German immigrants being more tolerant than native Austrians or other immigrant groups is contrary to hypothesis 8 but is it hard to draw valid conclusions due to the small sample size $(n=21)$ of this group.

Considering the emerging predictors of ethnocentrism on social integration, which were prominently highlighted by Aschauer and Mayerl (2019), the results were weaker than expected. Household income appears to be more relevant than subjective status measures, although a small additional influence of managing household income could be reported (partly confirming hypothesis 9). Surprisingly (contrary to hypothesis 10), measures of relative deprivation had no further impact on antiMuslim sentiment, but these effects may also be traced back to direct effects of education and income which remain stable after including those additional variables. Another explanation could be that the eleven indicators, which were used in the study, mainly target cultural threats while economic aspects are insufficiently represented in the scale. In line with this argument, the study showed a notable impact of political dissatisfaction on critical attitudes towards Muslims (partly confirming hypothesis 11). Recent studies show that cultural explanations have gained importance (e.g. Schneider 2008) and indicators of trust in particular are powerful concepts to explain a lack of solidarity towards immigrants (e.g. van der Linden et al. 2017). Citizens who are witnessing societal turbulence tend to perceive a certain futility of politics and react with higher social distrust when it comes to certain immigrant groups (confirmation of hypothesis 12). In this climate of ethnocentrism, it is not surprising that populists can gain supporters with a strong anti-Islam attitude. 
The core aim of this article was to take a closer look at the role of religion in potentially explaining critical attitudes towards Muslims. It is astonishing that various religious beliefs and behaviors exert a higher influence than aspects of the social structure and are far more relevant than current fears of societal decline. It seems that due to the sophisticated measurement of religious attitudes, the riddle of controversial results regarding the impact of religion on prejudice could be unraveled by notable impact factors.

While conventional religious beliefs and practices seem to increase prejudice (confirmation of hypothesis 13), a strong commitment to the role of religion in society-in the sense of an inclusive understanding of religion-seems to go hand in hand with more tolerance. These results are further enriched by additional explanatory factors, which correspond to the theses of an exclusive vs. inclusive understanding of religion by Allport and Ross (1967). The empirical findings show that people searching for a deeper sense of religion and who are open to spirituality (and esotericism) have a higher tolerance towards Muslims (confirmation of hypothesis 14). The effect of esotericism and spirituality may be linked to a kind of spiritual left-wing milieu, which may be generally open to other cultures and more tolerant towards different worldviews (for a further milieu-specific analysis see for instance Karstein and Benthaus-Apel 2012). Here, the research to further isolate the main drivers of tolerance based on individual religious-based lifestyles is in its infancy. These subjective forms of religiosity may be connected to certain basic values (such as benevolence) (e.g. Schwartz 1992) which may provoke a deeper understanding of the lifeworld of Muslims.

Finally, the construct of superstition, which is close to the concept of para-beliefs (Terwey 2012), increases prejudiced views on Muslims (confirmation of hypothesis 15). This may also be related to current societal developments because the internet and social media are taking on ever-greater importance in the public discourse. So people who are inclined to superstition may also be susceptible to follow conspiracy theories about Muslims.

It is an open question whether these results (based on SSÖ 2018 data) are only valid for Austria or whether these religious predictors exert similar influences in other European countries. It would be a major step forward to include at least some indicators on anti-Muslim sentiment in cross-national surveys and to give the measurement of religious beliefs a higher value in Europe-wide surveys. With enriched study designs focusing more prominently on religion, it would be possible to derive new emerging explanatory variables which are particularly relevant for explaining prejudice towards Muslims. This can further provide the basis for a better intercultural understanding.

Funding Open access funding provided by Paris Lodron University of Salzburg.

Open Access This article is licensed under a Creative Commons Attribution 4.0 International License, which permits use, sharing, adaptation, distribution and reproduction in any medium or format, as long as you give appropriate credit to the original author(s) and the source, provide a link to the Creative Commons licence, and indicate if changes were made. The images or other third party material in this article are included in the article's Creative Commons licence, unless indicated otherwise in a credit line to the material. If material is not included in the article's Creative Commons licence and your intended use is not permitted by statutory regulation or exceeds the permitted use, you will need to obtain permission directly 
from the copyright holder. To view a copy of this licence, visit http://creativecommons.org/licenses/by/4. $0 /$.

\section{References}

Adorno, Theodor W., Else Frenkel-Brunswik, Daniel J. Levinson, and R. Sanford Nevill. 1950. The authoritarian personality. New York: Harper \& Brothers.

Allen, Chris. 2007. Islamophobia and its consequences. In European Islam: challenges for public policy, ed. Samir Amghar, Amel Boubekeur, and Michael Emerson, 144-167. Brussels: Center for European Policy Studies.

Allport, Gordon W. 1954. The nature of prejudice. Reading: Addison-Wesley.

Allport, Gordon W., and J. Michael Ross. 1967. Personal religious orientation and prejudice. Journal of personality and social psychology 5(4):432-443.

Appel, Markus. 2012. Anti-immigrant propaganda by radical right parties and the intellectual performance of adolescents. Political Psychology 33(4):483-493.

Aschauer, Wolfgang. 2017. The multidimensional nature of Islamophobia: a mixed method approach to constructing the attitudes toward muslims scale (ATMS). Islamophobia Studies Journal 3(2):130-158.

Aschauer, Wolfgang, and Jochen Mayerl. 2019. The dynamics of ethnocentrism in Europe. A comparison of enduring and emerging determinants of solidarity towards immigrants. European Societies https:// doi.org/10.1080/14616696.2019.1616791.

Aschauer, Wolfgang, Martina Beham-Rabanser, Otto Bodi-Fernandesz, Max Haller, and Johanna Muckenhuber (eds.). 2019. Die Lebenssituation von Migrantinnen und Migranten in Österreich. Ergebnisse einer Umfrage unter Zugewanderten. Wiesbaden: Springer VS.

Bacher, Johann. 2017. Polarisierungstendenzen in Österreich: Ergebnisse einer latenten Klassenanalyse der Einstellungen zu Immigration. In Migration und Globalisierung in Zeiten des Umbruchs: Festschrift für Gudrun Biff, ed. Friedrich Altenburg, Anna Faustmann, Thomas Pfeffer, and Isabella Skrivanek, 379-397. Krems: Edition Donau-Universität Krems.

Batson, Charles D., Patricia Schoenrade, and W. Larry Ventis. 1993. Religion and the individual: a socialpsychological perspective. New York: Oxford University Press.

Bleich, Eric. 2011. What is Islamophobia and how much is there? Theorizing and measuring an emerging comparative concept. American Behavioral Scientist 55:1581-1600.

Burch-Brown, Joanna, and William Baker. 2016. Religion and reducing prejudice. Group Processes \& Intergroup Relations 19(6):784-807.

Ceobanu, Alin M., and Xavier Escandell. 2010. Comparative analysis of public attitudes toward immigrants and immigration using multinational survey data: a review of theories and research. Annual Review of Sociology 36:309-328.

Chandler, Charles R., and Yung Mei Tsai. 2001. Social factors influencing immigration attitudes: an analysis of data from the General Social Survey. The Social Science Journal 38(2):177-188.

Coenders, Marcel, and Peer Scheepers. 2003. The effect of education on nationalism and ethnic exclusionism: an international comparison. Political Psychology 24(2):313-343.

Coenders, Marcel, and Peer Scheepers. 2008. Changes in resistance to the social integration of foreigners in Germany 1980-2000: individual and contextual determinants. Journal of Ethnic and Migration Studies 34(1):1-26.

Commission on British Muslims and Islamophobia (ed.). 1997. Islamophobia. A challenge for us all. London. https://www.runnymedetrust.org/companies/17/74/Islamophobia-A-Challenge-for-Us-All. html. Accessed 3 Aug 2019.

Commission on British Muslims and Islamophobia (ed.). 2004. Islamophobia. Issues, challenges and action. Trent, sterling: Trentham books. http://www.insted.co.uk/islambook.pdf. Accessed 3 Aug 2019.

Dollard, John, Leonhard W. Doob, Neal E. Miller, O.H. Mowrer, and Robert S. Sears. 1971. Frustration und Aggression, 2nd edn., Weinheim: Beltz.

Dörre, Klaus, Klaus Kraemer, and Frederic Speidel. 2006. The increasing precariousness of the employment society: driving force for a new right wing populism? International Journal of Action Research 2:98-128.

Entzinger, Han. 2014. The growing gap between facts and discourse on immigrant integration in the Netherlands. Identities 21(6):693-707.

Fetzer, Joel S., and Christopher J. Soper. 2003. The roots of public attitudes toward state accommodation of European muslims' religious practices before and after September 11. Journal for the Scientific Study of Religion 42(2):247-258. 
Flecker, Jörg, and Sabine Kirschenhofer. 2007. Die populistische Lücke: Umbrüche in der Arbeitswelt und Aufstieg des Rechtspopulismus am Beispiel Österreichs. Berlin: Edition sigma.

Gesis-Leibnitz Institut für Sozialwissenschaften. 2013. Variable Reports, 80. Gruppenbezogene Menschenfeindlichkeit. GMF-Surveys 2002-2011. https://dbk.gesis.org/dbksearch/download.asp?id=51715. Accessed 3 Aug 2019.

Goujon, Anne, et al. 2017. Demographie und Religion in Österreich. Szenarien von 2016 bis 2046. Wien: Österreichischer Integrationsfonds. https://www.integrationsfonds.at/fileadmin/content/AT/Fotos/ Publikationen/Forschungsbericht/Forschungsbericht_Demographie_und_Religion_inkl_Vorwort_ Web.pdf. Accessed 13 Feb 2020.

Hadler, Markus, Franz Höllinger, and Johanna Muckenhuber. 2019. Social Survey Austria 2018 (SUF edition). https://doi.org/10.11587/ERDG3O. AUSSDA Dataverse, V2.0, retrieved on 3rd August, 2019.

Hafez, Farid. 2010. Islamophober Populismus. Moschee- und Minarettbauverbote österreichischer Parlamentsparteien. Wiesbaden: Springer-VS.

Hall, Stuart. 1989. Rassismus als ideologischer Diskurs. Das Argument 178:913-921.

Hall, Deborah L., C. Matz David, and Wendy Wood. 2010. Why don't we practice what we preach? A meta-analytic review of religious racism. Personality and social psychology review 14(1):126-139.

Hämmerle, Walter. 2018. Der neuе Kampf um Österreich. Die Geschichte einer Spaltung und wie sie das Land prägt. Wien: Edition A.

Heitmeyer, Wilhelm. 2007. Die Ideologie der Ungleichwertigkeit. Der Kern der Gruppenbezogenen Menschenfeindlichkeit. In Deutsche Zustände, Vol. 6, ed. Wilhelm Heitmeyer, 36-44. Frankfurt am Main: Suhrkamp.

Heitmeyer, Wilhelm (ed.). 2012. Deutsche Zustände. Vol. 1-10. Frankfurt am Main: Suhrkamp.

Heitmeyer, Wilhelm. 2012. Gruppenbezogene Menschenfeindlichkeit in einem entsicherten Jahrzehnt. In Deutsche Zustände, Vol. 10, ed. Wilhelm Heitmeyer, 15-41. Frankfurt am Main: Suhrkamp.

Helbling, Marc. 2010. Islamophobia in Switzerland. A new Phenomenon or a new name for Xenophobia. In Value Change in Switzerland, ed. Simon Hug, Hans Peter Kriesi, 65-80. Lanham: Lexington Books.

Helbling, Marc (ed.). 2012. Islamophobia in the west. Measuring and explaining individual attitudes. London: SAGE.

Hello, Evelyn, Peer Scheepers, and Mérove Gijsberts. 2002. Education and ethnic prejudice in Europe: explanations for cross-national variances in the educational effect on ethnic prejudice. Scandinavian Journal of Educational Research 46(1):5-24.

Imhoff, Roland, and Julia Recker. 2012. Differentiating Islamophobia: introducing a new scale to measure Islamoprejudice and secular Islam critique. Political Psychology 33(6):811-824.

Karstein, Uta, and Friederike Benthaus-Apel. 2012. Asien als Alternative oder Kompensation? Spirituelle Körperpraktiken und ihr transformatives Potential (nicht nur) für das religiöse Feld. In Körper, Sport und Religion. Zur Soziologie religiöser Verkörperungen, ed. Robert Gugutzer, Moritz Böttcher, 311-339. Wiesbaden: Springer VS.

Knoblauch, Hubert. 2018. Individualisierung, Privatisierung und Subjektivierung. In Handbuch Religionssoziologie, ed. Detlef Pollack, Volkhard Krech, Olaf Müller, and Markus Hero, 329-346. Wiesbaden: Springer VS.

Kühnel, Steffen, and Jürgen Leibold. 2007. Islamophobie in der deutschen Bevölkerung: Ein neues Phänomen oder nur ein neuer Name? Ergebnisse von Bevölkerungsumfragen zur Gruppenbezogenen Menschenfeindlichkeit 2003-2005. In Konfliktfeld Islam in Europa, ed. Monika Wohlrab-Sahr, Levent Tezcan, 135-154. Baden-Baden: Nomos.

Kunovich, Robert M. 2004. Social structural position and prejudice: an exploration of cross-national differences in regression slopes. Social Science Research 33(1):20-44.

Küpper, Beate, and Andreas Zick. 2014. Schützt Religiosität vor Menschenfeindlichkeit oder befördert sie sie? In Was heißt hier Toleranz?, ed. Andrea Bieler, Henning Wrogemann, 146-163. Neukirchen: Neukirchener Theologie.

Kurth, James. 2006. Europe's Identity Problem and the New Islamist War. Orbis 50:541-557.

Lee, Sherman A., et al. 2009. The Islamophobia scale: instrument development and validation. International Journal for the Psychology of Religion 19:92-105.

van der Linden, Meta, Marc Hooghe, Thomas de Vroome, and Colette Van Laar. 2017. Extending trust to immigrants: generalized trust, cross-group friendship and anti-immigrant sentiments in 21 European societies. PLOS ONE https://doi.org/10.1371/journal.pone.0177369.

Meeusen, Cecil, Thomas de Vroome, and Marc Hooghe. 2013. How does education have an impact on ethnocentrism? A structural equation analysis of cognitive, occupational status and network mechanisms. International Journal of Intercultural Relations 37(5):507-522. 
Olesen, Thomas. 2007. The porous public and the transnational dialectic: The Muhammed cartoons conflict. Acta Sociologica 50(3):295-308.

Pargament, Kenneth I. 1997. The psychology of religion and coping. Theory, Research, Practise. New York: Guilford.

Pickel, Gert, and Susanne Pickel. 2019. Der „Flüchtling“ als Muslim - und unerwünschter Mitbürger? In Flucht und Migration in Europa. Neue Herausforderungen für Parteien, Kirchen und Religionsgemeinschaften, ed. Oliver Hidalgo, Gert Pickel, 279-323. Wiesbaden: Springer VS.

Pickel, Gert, and Alexander Yendell. 2016. Islam als Bedrohung? Zeitschrift für vergleichende Politikwissenschaft 10(3-4):273-309.

Pollack, Detlef, Olaf Müller, Gergely Rosta, Nils Friedrichs, and Alexander Yendell (eds.). 2014. Grenzen der Toleranz. Wahrnehmung und Akzeptanz religiöser Vielfalt in Europa. Wiesbaden: Springer VS.

Pollack, Detlef, Nils Friedrichs, Olaf Müller, Gergely Rosta, and Alexander Yendell. 2010. Wahrnehmung und Akzeptanz religiöser Vielfalt. Eine Bevölkerungsumfrage in fünf europäischen Ländern. https://www.uni-muenster.de/imperia/md/content/soziologie/personen/pollack/religionssoziologie_ codebook_3.pdf. Accessed 8 Oct 2019.

Poynting, Scott, and Victoria Mason. 2007. The resistible rise of Islamophobia: anti-muslim racism in the UK and Australia before 11 September 2001. Journal of Sociology 43(1):61-86.

Prandner, Dimitri. 2019. Sozialer Survey Österreich. Methodik des Sozialen Survey Österreich. In Sozialstruktur und Wertewandel in Österreich. Trends 1986-2016, ed. Johann Bacher, Alfred Grausgruber, Max Haller, Franz Höllinger, Dimitri Prandner, and Roland Verwiebe, 515-531. Wiesbaden: Springer VS.

Quillian, Lincoln. 1995. Prejudice as a response to perceived group threat: population composition and anti-immigrant and racial prejudice in Europe. American Sociological Review 60:586-611.

Rebenstorf, Hilke. 2018. „Rechte“ Christen? - Empirische Analysen zur Affinität christlich-religiöser und rechtspopulistischer Positionen. Zeitschrift für Religion, Gesellschaft und Politik 2(2):313-333.

Saroglou, Vassilis, Bahija Lamkaddem, Matthieu Van Pachterbeke, and Coralie Buxant. 2009. Host society's dislike of the Islamic veil: The role of subtle prejudice, values, and religion. International Journal of Intercultural Relations 33(5):419-428.

Sarrazin, Thilo. 2010. Deutschland schafft sich ab: Wie wir unser Land aufs Spiel setzen. München: DTVerlagsanstalt.

Schneider, Silke L. 2008. Anti-immigrant attitudes in europe: outgroup size and perceived ethnic threat. European Sociological Review 1:53-67.

Schwartz, Shalom H. 1992. Universals in the content and structure of values: theoretical advances and empirical tests in 20 countries. Advances in Experimental Social Psychology 25:1-65.

Semyonov, Moshe, Rebeca Raijman, and Anastasia Gorodzeisky. 2006. The rise of anti-foreigner sentiment in European societies, 1988-2000. American Sociological Review 71(3):426-449.

Semyonov, Moshe, Rebeca Raijman, Anat Yom-Tov, and Peter Schmidt. 2004. Population size, perceived threat, and exclusion: a multiple-indicators analysis of attitudes toward foreigners in Germany. Social Science Research 33(4):681-701.

Statistics Austria (ed.). 2017. Migration \& Integration. Zahlen.Daten.Indikatoren 2017. https://www. integrationsfonds.at/fileadmin/content/AT/Downloads/Publikationen/Statistisches_Jahrbuch_ migration_integration_2017.pdf. Accessed 3 Aug 2019.

Steele, Claude M., J. Spencer Steven, and Joshua Aronson. 2002. Contending with group image: the psychology of stereotype and social identity threat. In Advances in experimental social psychology, ed. Mark Zanna, 379-440. San Diego: Academic Press.

Stolz, Jörg. 2005. Explaining Islamophobia. A test of four theories based on the case of a Swiss city. Swiss Journal of Sociology 31(3):547-566.

Storm, Ingrid. 2012. Säkulares Christentum als nationale Identität: Religion und Anti-Immigrationseinstellungen in vier westeuropäischen Ländern. In Religiöser Pluralismus im Fokus quantitativer Religionsforschung, ed. Detlef Pollack, Ingrid Tucci, and Hans Georg Zieberts, 331-370. Wiesbaden: Springer VS.

Stouffer, Samuel A., et al. 1949. Adjustment during army life. Studies in social psychology in world war II: the American soldier, Vol. 1. Princeton: Princeton University Press.

Strabac, Zan, and Ola Listhaug. 2008. Anti-Muslim prejudice in Europe. A multilevel analysis of survey data from 30 countries. Social Science Research 37:268-286.

Tajfel, Henri, and John C. Turner. 1979. An integrative theory of intergroup conflict. In The social psychology of intergroup relations, ed. William G. Austin, Stephen Worchel, 33-47. Monterey: BrooksCole. 
Taylor, Marylee C. 1998. How white attitudes vary with the racial composition of local populations: numbers count. American Sociological Review 63(4):512-535.

Terwey, Michael. 2012. Wachsender religiöser Pluralismus in der Gegenwart? Seriöse Umfrageergebnisse als Prüfstand. In Religiöser Pluralismus im Fokus quantitativer Religionsforschung, ed. Detlef Pollack, Ingrid Tucci, and Hans Georg Zieberts, 107-131. Wiesbaden: Springer VS.

Triandafyllidou, Anna. 1998. National identity and the "other". Ethnic and Racial Studies 21(4):593-612.

Urban, Dieter, and Jochen Mayerl. 2011. Regressionsanalyse: Theorie, Technik und Anwendung. Wiesbaden: Springer VS.

Urban, Dieter, Jochen Mayerl, and Andreas Wahl. 2016. Regressionsanalyse bei fehlenden Variablenwerten (missing values): Imputation oder Nicht-Imputation? Eine Anleitung für die Regressionspraxis mit SPSS. Schriftenreihe des Instituts für Sozialwissenschaften der Universität Stuttgart, Nr. 44. https://www.sowi.uni-stuttgart.de/dokumente/forschung/siss/SISS44.pdf. Accessed 15 Feb 2020.

Yendell, Alexander, and Nils Friedrichs. 2012. Wahrnehmung und Akzeptanz religiöser Vielfalt in ausgewählten europäischen Ländern. In Religiöser Pluralismus im Fokus quantitativer Religionsforschung, ed. Detlef Pollack, Ingrid Tucci, and Hans Georg Zieberts, 265-298. Wiesbaden: Springer VS.

Zick, Andreas, Beate Küpper, and Andreas Hövermann. 2011. Die Abwertung der Anderen. Eine europäische Zustandsbeschreibung zu Intoleranz, Vorurteilen und Diskriminierung. Berlin: Friedrich Ebert Stiftung Forum. http://library.fes.de/pdf-files/do/07905-20110311.pdf, retrieved on 3rd August, 2019.

Zick, Andreas, Carina Wolf, Beate Küpper, Eldad Davidov, Peter Schmidt, and Wilhelm Heitmeyer. 2008. The syndrome of group-focused enmity: the interrelation of prejudices tested with multiple crosssectional and panel data. Journal of Social Issues 64(2):363-383.

Wolfgang Aschauer Assoz. Prof. PD MMag. Dr.; von 2007 bis 2011 Postdoc; 2011-2015 Assistenzprofessor, seit März 2016 Assoziierter Professor am Fachbereich Politikwissenschaft und Soziologie, Abteilung Soziologie und Kulturwissenschaft mit den Schwerpunktthemen soziale Integrationsforschung (Migration, Integration, gesellschaftlicher Zusammenhalt), quantitative Methoden/ländervergleichende Sozialforschung und Tourismusforschung. 